\title{
The Beyșehir-Hoyran-Hadim Nappes: genesis and emplacement of Mesozoic marginal and oceanic units of the northern Neotethys in southern Turkey
}

\author{
THEO ANDREW \& ALASTAIR H. F ROBERTSON \\ Department of Geology and Geophysics, University of Edinburgh, Edinburgh EH9 3JW, UK \\ (e-mail: tandrew@glg.ed.ac.uk)
}

\begin{abstract}
The Beyșehir-Hoyran-Hadim Nappes crop out over $700 \mathrm{~km}$ from NW to SE. Above a regionally autochthonous Tauride carbonate platform the Beyșehir-Hoyran Nappes begin with a thrust sheet (c. $400 \mathrm{~m})$ of mainly redeposited carbonates, quartzose sandstones and mudstones of Mid-Late Triassic age, interpreted as a proximal slope-base-of-slope succession. Above is a thrust sheet $(c .1 \mathrm{~km})$ of Middle-Upper Triassic intermediate-acidic extrusive rocks, volcaniclastic rocks and minor pelagic carbonates, interpreted as a continental rift. Thin $(<100 \mathrm{~m})$ Upper Triassic-Upper Cretaceous pelagic carbonate and radiolarian chert lie depositionally above. The uppermost thrust sheet comprises broken formation and mélange, including Jurassic shallow-water carbonate, radiolarian chert and Upper Cretaceous pelagic limestone. Zones of tectonicsedimentary mélange separate higher units. The Beyșehir-Hoyran Nappes document Triassic rifting and Jurassic-Cretaceous passive margin subsidence bordering the Northern Neotethys. A harzburgitic ophiolite probably formed above a north-dipping subduction zone within the ocean basin. The ophiolite was emplaced southwards onto the northern margin of the Tauride platform in latest Cretaceous time. The nappe pile and underlying platform (Hadim Nappe) were thrust further south in Late Eocene time. Assuming in-sequence thrusting, the Beyșehir-Hoyran Nappes restore to a location north of a Neotethyan spreading axis. More probably, they originated near the south margin of the Northern Neotethys, but reached their position by outof-sequence thrusting. Formation within a southerly strand of the Northern Neotethys (Inner Tauride ocean) is more probable than within the main Northern Neotethys further north.
\end{abstract}

Keywords: Turkey, Neotethys, tectonics, thrust sheets, orogeny.

Many emplaced continental margins are structurally complex and have experienced multiple deformation events. Attempts to restore such margins depend critically on whether in-sequence ('piggy-back') thrusting can be assumed. For example, in the Tethyan regions, most reconstructions have assumed in-sequence thrusting (e.g. Othris, Greece; Smith et al. 1979; Pindos, Greece; Fleurry 1980; Degnan \& Robertson 1998; Antalya, SW Turkey; Robertson 1993). However, out-of-sequence thrusting has been shown to play a role in some emplaced continental margins (e.g. Oman; Searle et al. 1990). Here, we consider the example of the regionally extensive Mesozoic Beyșehir-Hoyran Nappes within the central Taurus Mountains, southern Turkey (Fig. 1). We reconstruct their tectonic evolution and palaeogeography based on new sedimentological, structural and igneous geochemical data, combined with integration of existing tectonostratigraphical information. We consider alternative in-sequence v. out-ofsequence thrust reconstructions with implications for comparable emplaced contintental margins elsewhere.

Since their discovery byBlumenthal $(1947,1951,1956,1960-$ 1963), the regional tectonostratigraphy of the Beysehir-Hoyran Nappes was established by Monod (1977) and byÖzgül (1976, 1997). In addition, various parts of the Beyșehir-Hoyran Nappes and related relatively autochthonous units were studied by a number of workers, including Haude (1969), Koçyiğit (1976), Gutnic (1977), Gutnic et al. (1968, 1979), Gökdeniz (1981) and Demirkol (1984). More recently, part of the area was remapped by the Turkish Maden Tetkik ve Arama (Maden Tektik ve Arama Genel Müdürlü ğü 1997; Șenel et al. 1998).

The Beysehir-Hoyran Nappes include Mesozoic carbonate platform, deep-sea and ophiolitic units that were seen as part of a vast unit (Bozkir Nappes; Özgül \& Arpat 1973), including the
Lycian Nappes to the west, that were thrust from a Northern Neotethyan ocean basin onto the Anatolide-Tauride carbonate platform to the south in latest Cretaceous time (Șengör \& Y1lmaz 1981; Tekeli 1981; Robertson \& Dixon 1984; Dercourt et al. 1986, 1992; Stampfli 2000).

Below, we outline the tectonostratigraphy and age relations of units within four representative areas, from east to west, and demonstrate a regional coherence over $c$. $700 \mathrm{~km}$, allowing overall tectonic reconstructions (Figs. 1 and 2).

\section{Regional setting}

We summarize each unit from NW to SE below.

\section{Dinar area}

The Dinar Units (Fig. 1) were previously correlated with the Lycian Nappes (Özgül \& Arpat 1973; Gutnic 1977; Gutnic et al. 1979), but are grouped here with the Beyșehir-Hoyran-Hadim Nappes in view of similarities in tectonostratigraphy and timing of emplacement. The most westerly, volumetrically smallest, outcrop area of the nappes, known as the Hoyran Nappes of the Pisidian Taurus (Gutnic et al. 1979), comprise four main thrust sheets (Figs. 2 and 3) above an autochthon (Sandikli Series). The latter comprises Precambrian and Palaeozoic 'basement' (Gutnic 1977; Göncüoğlu \& Kozlu 2000) overlain by Lower Jurassic siliciclastic sedimentary rocks, which are in turn unconformably overlain by Middle Jurassic to Upper Cretaceous platform carbonates (Fig. 4a). At the top, neritic carbonates pass into Maastrichtian pink pelagic limestones, including the planktonic foraminifera Globotruncana stuarti, G. caliciformis, G. arca, G. 


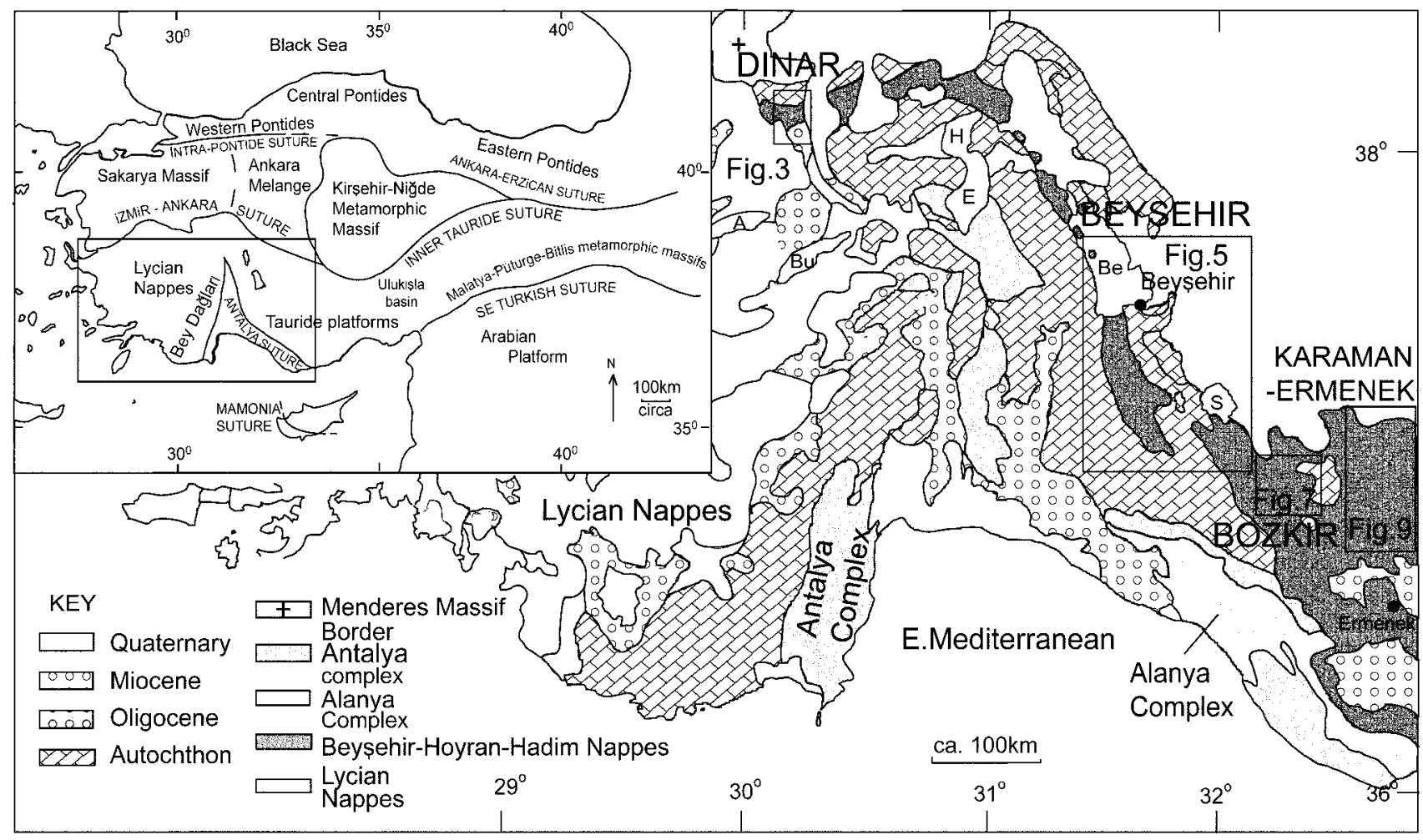

Fig. 1. Tectonostratigraphic map of SW Turkey (after Gutnic et al. 1979). A, Lake Açı; Bu, Lake Burdur; H, Lake Hoyran; E, Lake Eğirdir; Be, Lake Beyșehir; S: Lake Suğla. Inset: main tectonic subdivisions of Turkey.

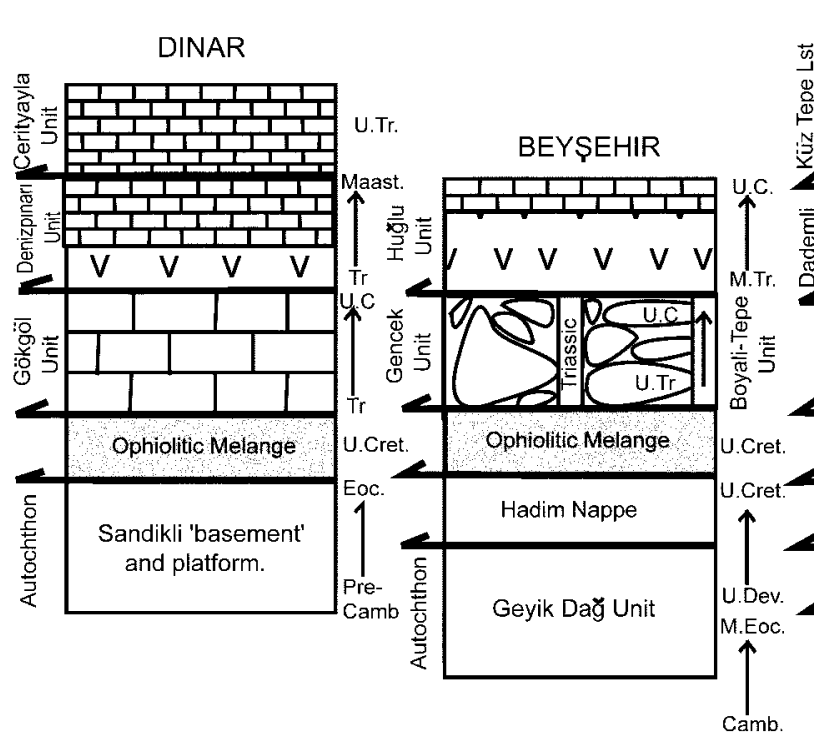

a)

b) c)
BOZKIR

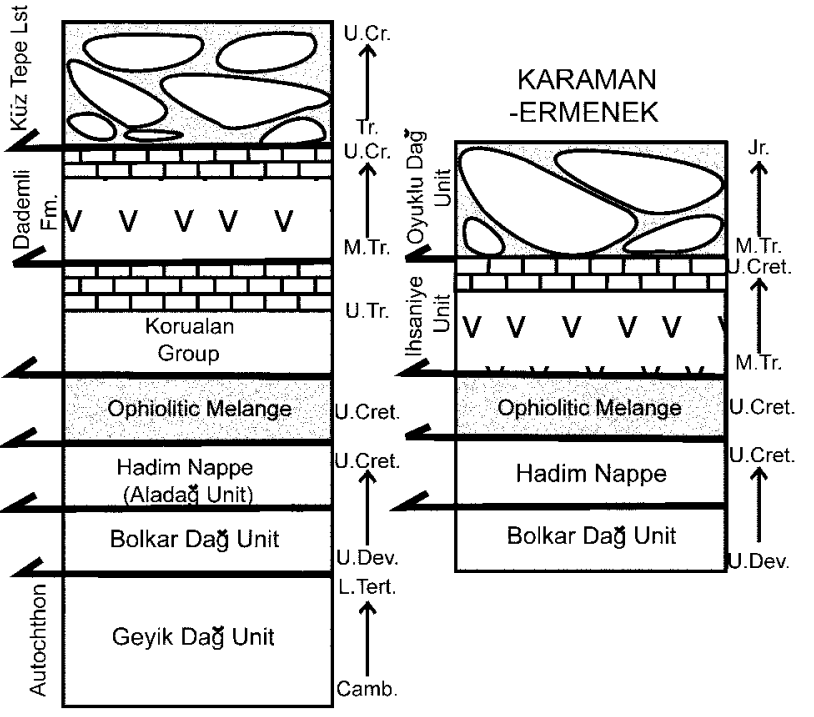

d)

Fig. 2. Tectonostratigraphic correlation of the Beyșehir-Hoyran-Hadim Nappes. (Note the similarities in tectonostratigraphy over $c .300 \mathrm{~km}$ from NW to SE.) The Hadim Nappe (not present in the Dinar area) is at the base, followed by the Upper Cretaceous Ophiolitic Mélange (including ophiolite slices), in turn overlain by up to five distinct thrust sheets of Mid-Triassic to Late Cretaceous age.

contusa, G. helvetica and G. linnei (Gutnic 1977). Depositionally above are siliciclastic sedimentary rocks, debris flow deposits and slumps containing Early to Mid-Eocene large foraminifera (e.g. Nummulites) (Gutnic 1977).

The Hoyran Nappes (Fig. 2a) begin with Ophiolitic Mélange
(Fig. 3). Above, the Gökgöl Unit ( $<500 \mathrm{~m}$ thick) comprises overturned Triassic-Upper Lias neritic dolomite and limestone, depositionally overlain by a Toarcian to Upper Cretaceous pelagic succession (Fig. 4b). Above this, the Denizpınarı Unit ( $<900 \mathrm{~m}$ thick) comprises sheared lavas interbedded with, and 


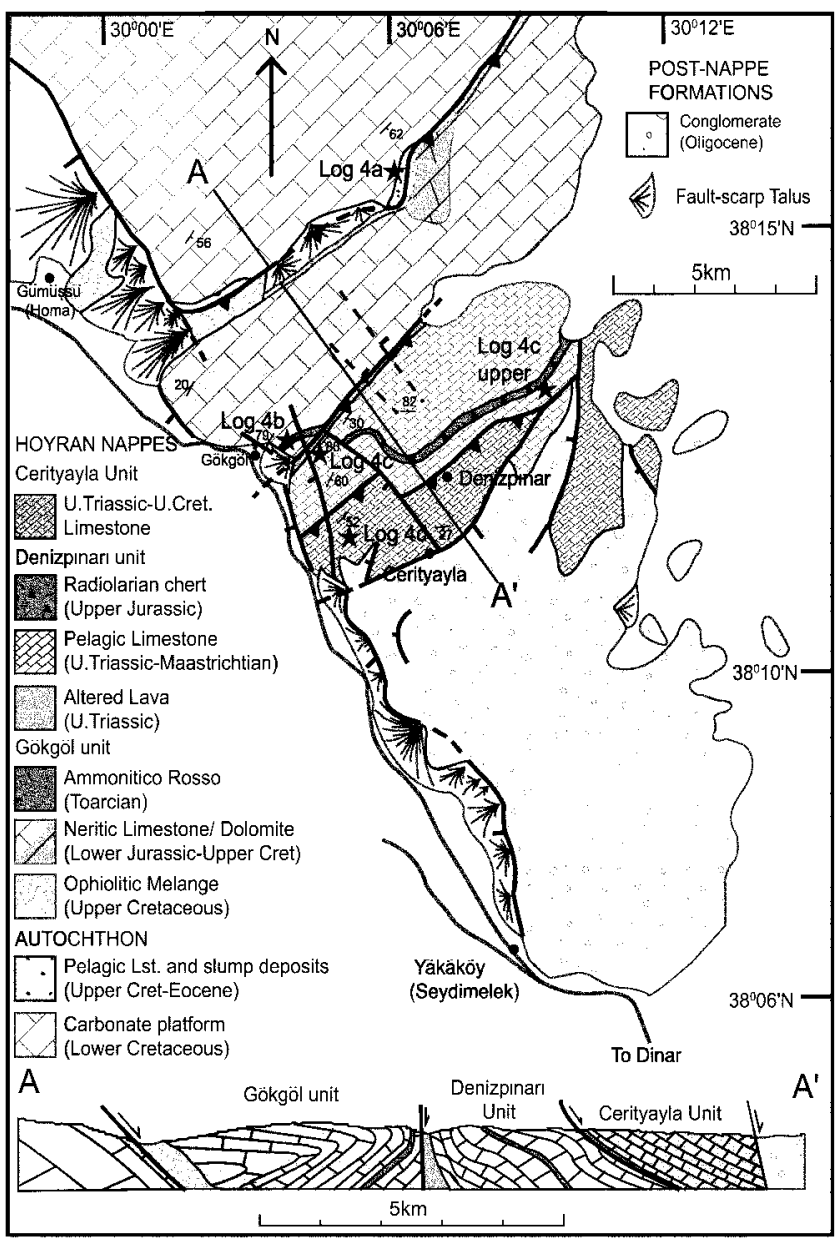

Fig. 3. Geological map and cross-section of the Beyșehir-Hoyran Nappes to the north of Dinar (modified from Gutnic 1977).

overlain by, Triassic pelagic limestones, followed by a pelagic sequence including Upper Jurassic radiolarian chert and Upper Cretaceous pelagic limestones, rich in Globotruncana sp. (Fig. 4c; Gutnic 1977). Finally, the third nappe, the Cerityayla Unit (c. $400 \mathrm{~m}$ ), consists mainly of Triassic pelagic limestones (Fig. 4d).

\section{Beyşehir area}

Lake Beyșehir is the type area owing to excellent exposure and clear structural relationships (Monod 1977; Figs. 1, 2 and 5). The Mesozoic autochthonous succession (Beyșehir Series, Seydisehir Series and Akseki platform) is similar to the Sandikli Series of the Dinar area. Both exhibit a Palaeozoic basement of regionally similar units (Dean \& Özgül 1994) unconformably overlain by Upper Triassic-Lower Jurassic siliciclastic rocks and Mesozoic-Lower Eocene platform carbonates, culminating in Mid-Eocene siliciclastic turbidites and debris flow deposits (i.e. Geyik Dağ Unit; Özgül 1976). Stratigraphic gaps, marked by basal conglomerates and bauxite horizons, commonly occur in the Cenomanian sequence in northeasterly areas of the central Taurides (Özgül 1976; Monod 1977).

Four main thrust sheets are present above the local autochthon (Fig. 2b). The lowest, the Hadim Nappe in the SW (Fig. 6a), begins with Upper Devonian shales, sandstones and quartzites with carbonate intercalations, overlain by Carboniferous shales, limestones and quartzites. The Permian period is represented by thick ( $>1500 \mathrm{~m}$ ) shallow-water limestones (Özgül 1976; Monod 1977). The succession passes into Lower Triassic limestone and shale, overlain by Middle Triassic siliciclastic rocks, then uppermost Triassic red sandstone and conglomerate. The red clastic interval is correlated with similar facies in the autochthon (e.g. Çayir Formation and Üzümdere Formation; Monod \& Akay 1984). The Jurassic-Upper Cretaceous sequence of the Hadim Nappe (Çamlık Unit, Fig. 6a) is characterized by platform carbonates (Özgül 1976; Monod 1977).

The overlying Upper Cretaceous Ophiolitic Mélange (Fig. 2) includes amphibolite interpreted as a metamorphic sole (e.g west of Gencek village), and a dismembered ophiolite, mainly serpentinized harzburgite and dunite. Slices of Permian fusulinid limestone occur locally beneath the ophiolite (Monod 1977). The Ophiolitic Mélange is overthrust by the Gencek Unit (Figs. 2 and 6b), consisting of Triassic massive neritic limestone, including the large bivalve Megalodon. Further north, at a similar structural level, a more complete succession is known as the Boyali-Tepe Unit (Figs. 2 and 6c). This consists of well-bedded Upper Triassic neritic limestone, depositionally overlain by a Lower Jurassic to Upper Cretaceous pelagic sequence, including Toarcian to Mid-Jurassic Ammonitico Rosso and Upper Cretaceous Globotruncana-bearing pelagic limestone (Monod 1977). The succession ends with a polygenetic debris flow deposit, with ophiolite-derived clasts. This unit can be traced tens of kilometres NW along the north shore of Lake Beyșehir. Both the Gencek and the Boyali-Tepe Units are fragmented and form up to kilometre-sized blocks and a dismembered thrust sheet set in a sandy matrix ('Wildflysch'). The matrix includes radiolarian chert, neritic limestone, pelagic limestone, calcarenite and detrital quartz.

Above is the Huğlu Unit (Fig. 6d), which comprises a Middle Triassic volcanogenic sequence of interbedded green siliceous lava, fine-grained volcaniclastic sandstone-siltstone and green ribbon chert ('tuffite'), also minor redeposited limestone and coarse-grained volcaniclastic sediment (particularly near the base). Permian fusulinid limestone is found as rare lithic fragments within basalt lava flows (Monod 1977). Analyses of lava samples reveal a variable $\mathrm{SiO}_{2}$ content (49.9-69.9\%; Table 1). Above follows an intact succession of Upper Triassic-Upper Cretaceous pelagic carbonates (Monod 1977).

\section{Bozkir area}

Above the regional autochthon (Geyik Dağ; Özgül 1976), are the Bolkar Dağ Unit and the Hadim Nappe (Aladağ Unit; Fig. 7) in a structurally low position, followed by the Upper Cretaceous Ophiolitic Mélange and a dismembered ophiolite (Özgül 1997). Above, the Upper Triassic Korualan Group (c. $200 \mathrm{~m}$ thick) begins with $c .40 \mathrm{~m}$ of dolomite, followed by $c .100 \mathrm{~m}$ of turbiditic siltstone, sandstone and redeposited limestone, culminating in an undated (recrystallized) pelagic limestone and chert sequence (Fig. 8a).

The middle thrust sheet (Fig. 8b) is a Middle-Upper Triassic volcanogenic succession (Dedemli Formation), with an Upper Triassic-Upper Cretaceous pelagic carbonate cover (Mahmut Tepe Formation; Özgül 1997). The MiddleTriassic succession is dominated by basic-intermediate composition lava, green volcaniclastic siltstone and interbedded pelagic limestone of Carnian age (Tekin 1999). The uppermost unit (Fig. 8c) is a dismembered succession of Triassic-Lower Jurassic neritic carbonates overlain by Toarcian-Upper Cretaceous pelagic carbonates and radiolarian chert, locally termed the Küz Tepe, Asar Tepe and Soğucak Formations (Özgül 1997). 


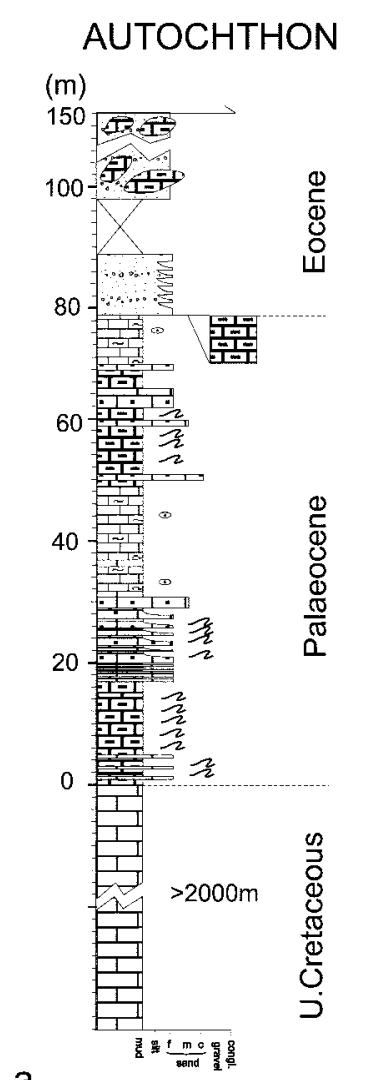

a.

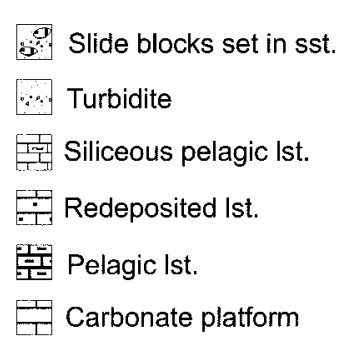

b.

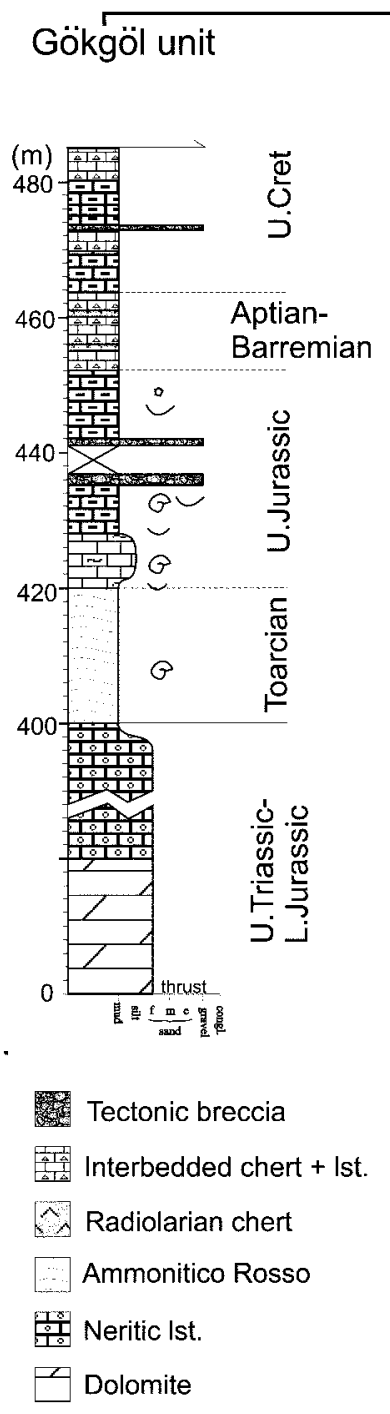

\section{HOYRAN NAPPES}

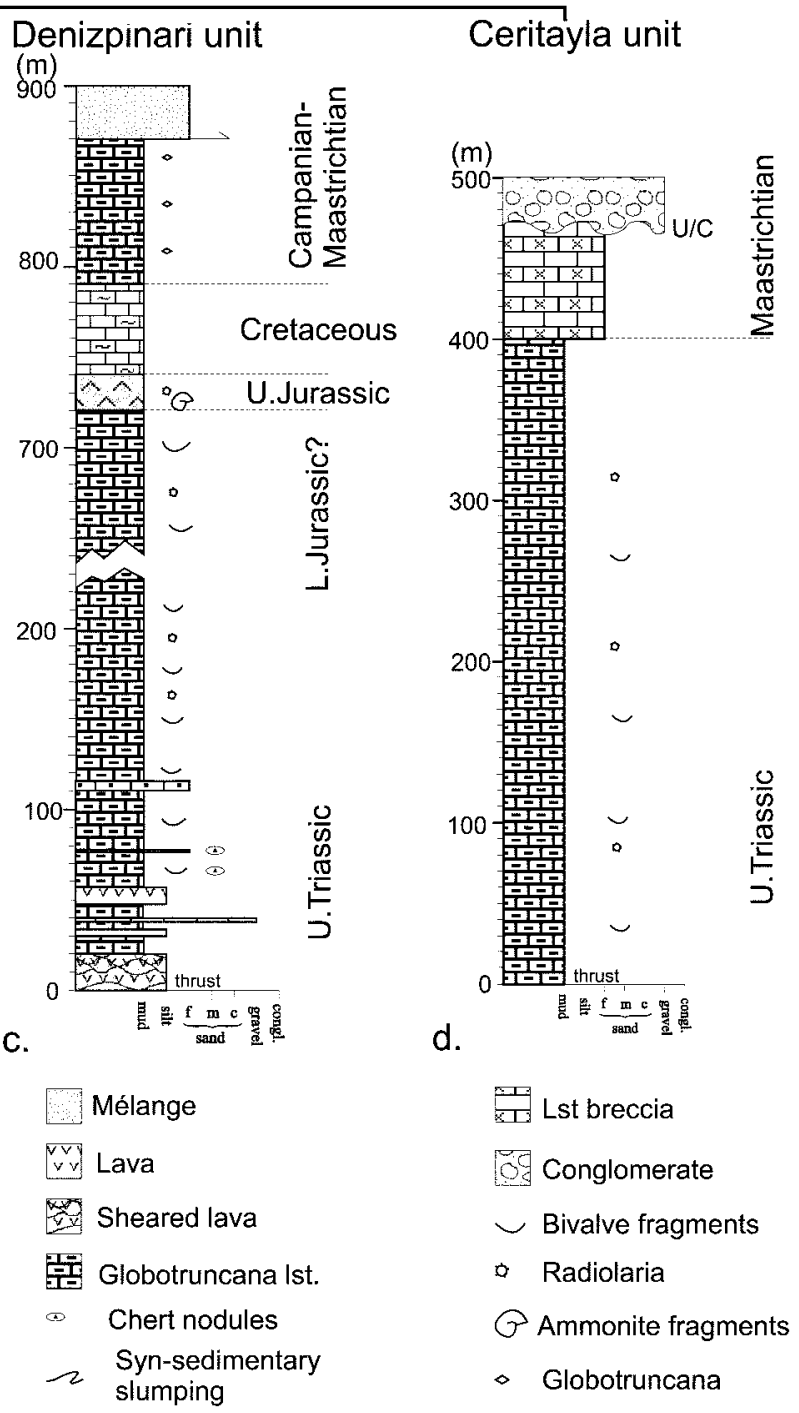

Fig. 4. Measured sedimentary logs of the Beyșehir-Hoyran units in the Dinar area. (See Fig. 3 for location of logs.)

\section{Ermenek-Karaman area}

The easternmost area of the Beyșehir-Hoyran-Hadim Nappes covers $c .100 \mathrm{~km}$ (Figs. 9 and 10). The lowest exposed unit is the relatively autochthonous Mesozoic Bolkar Dağ Unit, which is overlain by Ophiolitic Mélange and higher units. The Hadim Nappe is exposed as a separate unit further south. Ophiolite (other than mélange) crops out only south of Ermenek, outside the main study area. The structurally higher, internally imbricated, Ihsaniye Unit exposed in both the Ermenek and Karaman areas (Fig. 11a and b) begins with Triassic siliciclastic turbidites (locally with plant remains), basic-intermediate composition lava and thin-bedded volcaniclastic sediment, all overlain by a thick succession $(>200 \mathrm{~m})$ of fine-grained, green volcaniclastic sediment (Gökdeniz 1981). An Upper Triassic-Upper Cretaceous pelagic limestone sequence follows, with a thick $(>80 \mathrm{~m})$ tectonically imbricated radiolarian chert horizon. The overlying Oyuklu Dağ Unit comprises Triassic to Jurassic massive neritic carbonates (Fig. 11c). Further north, in the Karaman area (Fig. 9), the Bolkar Dağ Unit culminates in a thick monomict limestone breccia and is tectonically overlain by heterogeneous kilometre-sized blocks and disrupted sheets of Ihsaniye and Oyuklu Dağ unit-type lithologies in a sheared ophiolite-derived matrix.

\section{Regional interpretation}

\section{Regional autochthon (Geyik Dă̆ Unit)}

The Upper Precambrian to Cambrian Sandikli Series is interpreted as Pan-African continental basement (Dean \& Özgül 1994; Göncüoğlu 2001), overlain by Upper Triassic shales and siliciclastic sediments deposited on a rifted fragment of the north Gondwana shelf. Overlying shallow-water carbonates of MidLate Triassic age record a subsiding Bahama-type carbonate platform adjacent to Neotethys. Fluvial to shallow-marine clastic sediments (Çayir Formation) of latest Triassic age record faultrelated uplift and erosion of the underlying basement (Monod \& Akay 1984), possibly a compressional effect related to the final emplacement of the Karakaya Complex in the Pontides further north (Robertson \& Pickett 2000). Carbonates and passive margin subsidence dominated the remainder of Mesozoic time, 


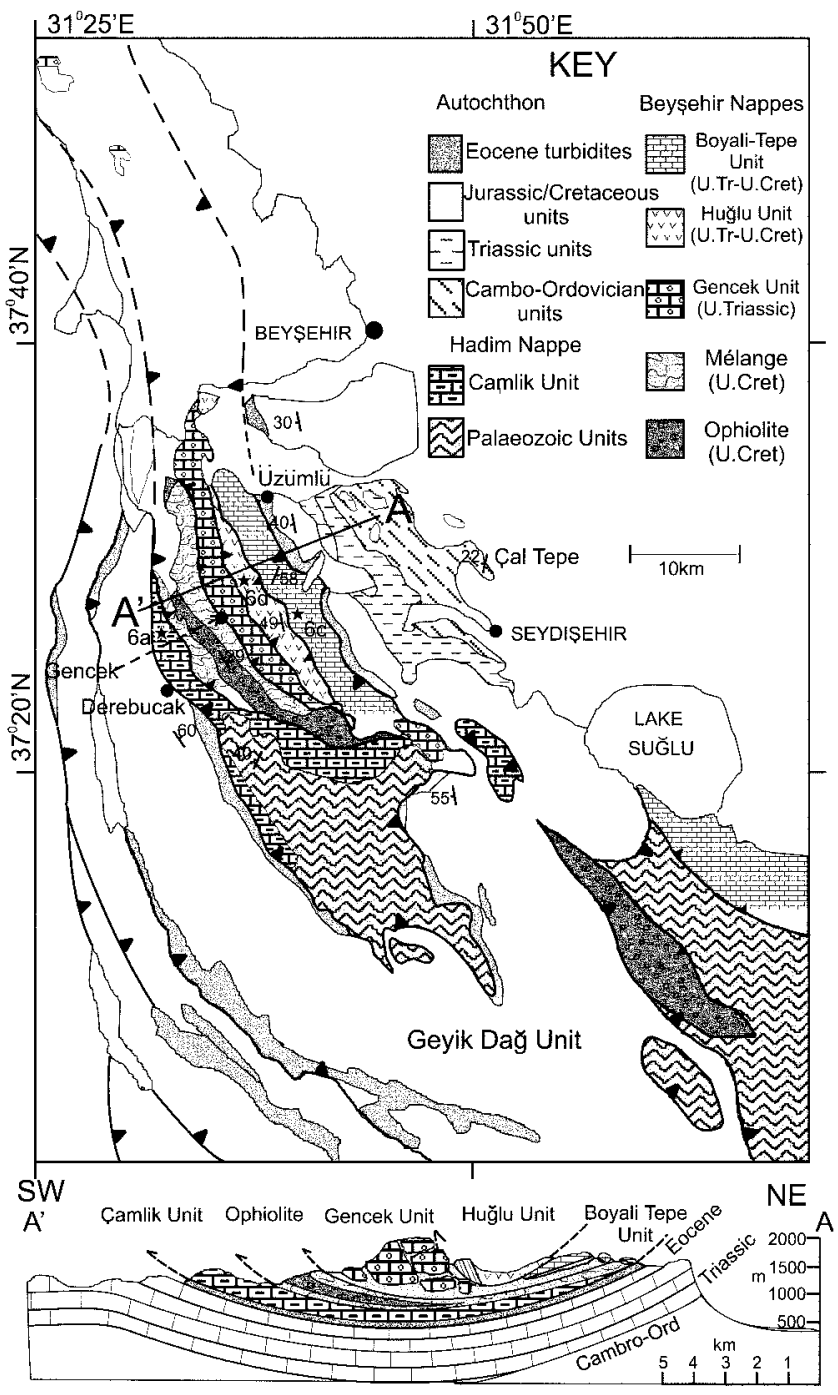

Fig. 5. Geological map and cross-section of the Beyșehir-Hoyran Nappes in the Beyșehir area (modified from Monod 1977).

with a switch to deeper pelagic carbonate deposition in Late Cretaceous time. The exposed autochthon remained largely unaffected by regional events, including Late Cretaceous ophiolite emplacement. However, a switch to pelagic carbonate and deepening in Late Cretaceous time was possibly tectonically controlled. During Late Eocene time the platform subsided as a flexural foredeep ahead of the emplacement of the BeyșehirHoyran-Hadim Nappes.

\section{Hadim Nappe}

Where present, the Hadim Nappe exhibits a similar PalaeozoicCretaceous succession to the autochthon. The Upper DevonianUpper Cretaceous succession records a shallow-marine carbonate platform setting, punctuated by emergence and erosion in latest Triassic time, coinciding with the deposition of shallow-marine to fluvial clastic sediments (Çayir Formation; Monod \& Akay 1984). However, the Geyik Dağ Autochthon and Hadim Nappe differ in the Upper Cretaceous units as Ophiolitic Mélange is present on the latter, showing that the Hadim Nappe was overthrust by oceanic crust, which, however, did not reach the
Geyik Dağ further south. The Hadim Nappe and Bolkar Dağ Unit are seen as facies variants within the original Tauride carbonate platform (Geyik Dağ), with the Bolkar Dağ Unit, in particular, showing a relatively thin and variable succession.

\section{Ophiolitic Mélange}

Ophiolitic Mélange is always at the same relative structural position, i.e. above the Hadim Nappe (where present), but below the Upper Nappes (Fig. 2). Ophiolitic Mélange is also found at structurally higher levels in both the Bozkir and northern Ermenek-Karaman areas, usually as the matrix of dismembered units ('broken formation'). The mélange is dominated by a chaotic admixture of neritic and pelagic limestone, radiolarian chert, basic volcanic rocks, serpentinite, volcaniclastic sediments (including debris flow deposits), gabbro and amphibolite, set in a sheared, incompetent matrix of ophiolite-derived sandstone and mudstone. In the Beyșehir region, kilometre-sized blocks of fusulinid-bearing Permian limestone occur directly beneath the ophiolite (Monod 1977). A crude layering is present, marked by different compositions of blocks in the Beyșehir area. The mélange matrix is dated to Late Cretaceous (Maastrichtian) time based on planktonic foraminifera, including Globotruncana arca, from blocks of pink pelagic limestone in the Bozkir area (Özgül 1997).

Whole-rock XRF analysis of basaltic clasts from the Ophiolitic Mélange in the Beyșehir and Dinar areas reveals the presence of two compositional groups (Fig. 12a and b; Table 1). One is relatively enriched in the high field strength elements (HFSE) compared with normal mid-ocean ridge basalt (N-MORB) (Fig. $12 \mathrm{~b}$ ) and shows within-plate affinities in tectonic discrimination diagrams (Fig. 13). The second shows minor depletion in HFSE, with marked $\mathrm{Nb}$ depletion (Fig. 12a), suggestive of formation in a subduction-influenced setting (Pearce et al. 1984).

The dominantly deep-sea nature of the mélange matrix and the similarity of deformation fabrics to modern oceanic forearc complexes (e.g. the Barbados arc; Mascle \& Moore 1990) suggest that the mélange is a subduction-accretion complex. The basaltic blocks within the mélange are interpreted as accreted Tethyan oceanic crust erupted at both oceanic ridge (MORBsupra-subduction zone (SSZ)) and seamount settings (withinplate affinities).

The accretionary prism included relatively near-margin units that were incorporated during initial Maastrichtian tectonic emplacement over the continental margin (i.e. Triassic riftrelated neritic limestone), and pre-rift Permian fusulinid limestone in the Beysehir area.

No mélange lithologies younger than Late Cretaceous (Maastrichtian) time are known in the mélange in the central and eastern areas (Bozkir-Ermenek), suggesting that the accretion had ended by this time.

\section{Ophiolite}

Large coherent slices of serpentinized peridotite occur within the Ophiolitic Mélange in several areas, e.g. to the north and south of Lake Beyșehir, Bozkir (Dipsiz Göl) and to the south of the Ermenek area. At present, these are dated only to pre-Maastrichtian time by the age of the mélange matrix and the metamorphic sole (Ö. F. Çelik, pers. comm.). An amphibolite-facies metamorphic sole locally occurs beneath the peridotite and is well exposed north of Lake Beyșehir (Elitok 2000). Greenschist- and amphibolite-facies rocks, probably also fragments of meta- 
HADIM NAPPE

\section{Çamlık Unit}

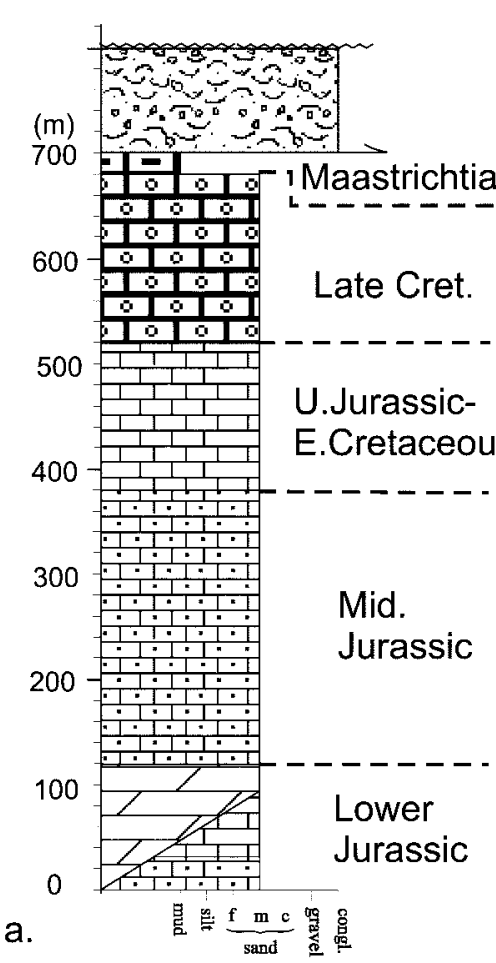

\section{BEYSEHIR NAPPE}

Boyali-Tepe Unit Huğlu Unit

(m)

(m)

300

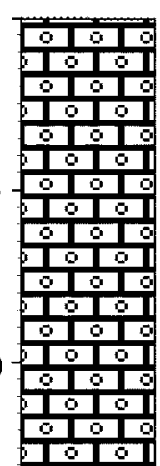

350

340
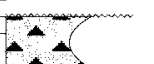

(m)

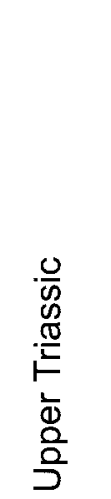

200
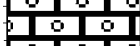

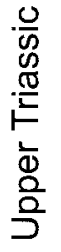

100
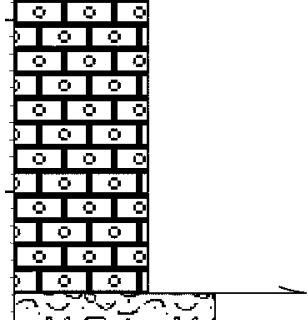

0

b.
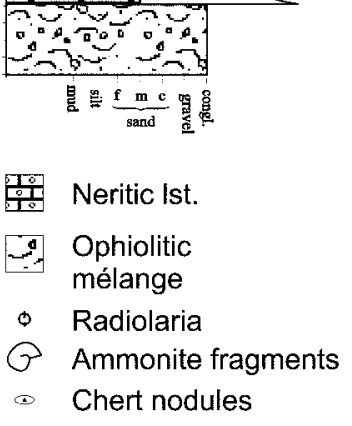
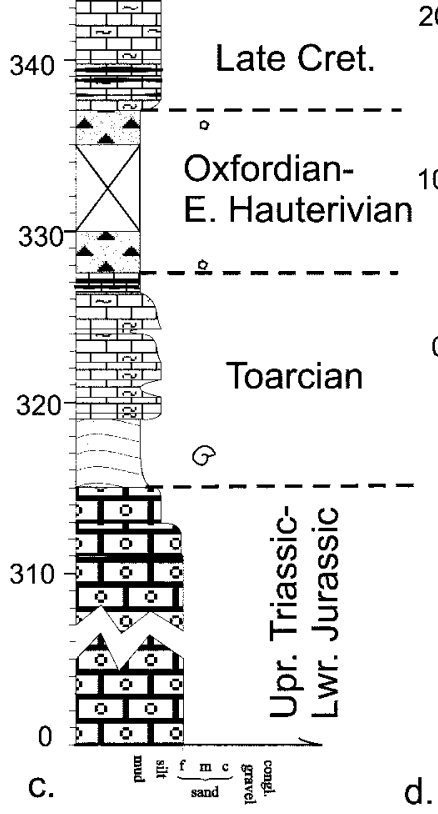

d.

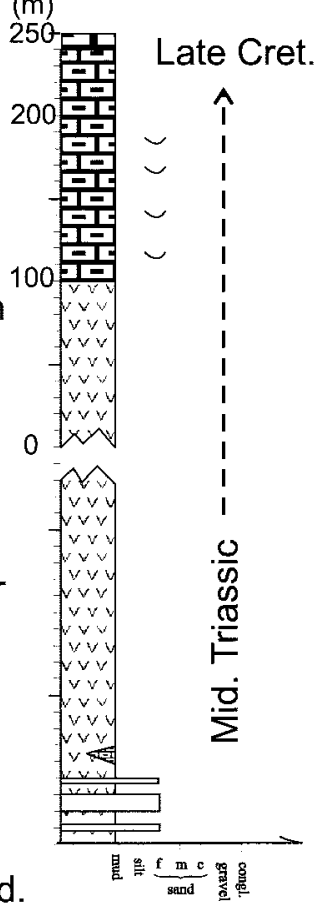

Fig. 6. Measured sedimentary logs of the Beyșehir-Hoyran units in the Beyșehir area. (See Fig. 5 for location of logs $6 a$ and $6 b$ adapted from Monod (1977).)

morphic sole, occur locally as detached blocks within the Ophiolitic Mélange (Monod 1977).

The peridotite is dominantly serpentinized harzburgite, ranging from fresh to $70 \%$ altered, with minor pyroxenite, dunite and chromite pods (Elitok 2000). Dolerite dykes that cut the peridotite show chilled margins and local metasomatic calcic alteration.

Whole-rock XRF analysis of relatively unaltered peridotite (Fig. 14a) reveals $\mathrm{Cr}$ and $\mathrm{Ti}$ contents comparable with inferred supra-subduction zone-type (SSZ) ophiolites (Pearce et al. 1984). Analysis of chrome spinel grains, using an electron microprobe, confirms enrichment in $\mathrm{Cr}$ relative to $\mathrm{Mg}$ (Fig. 14b), as in present-day island-arc rocks and inferred SSZ-type ophiolites (e.g. Oman ophiolite, Dick \& Bullen 1984). Peridotite from north of Lake Beyșehir, when normalized to N-MORB, shows enrichment in large ion lithophile elements (LILE) relative to HFSE. Such enrichment is attributed to mantle wedge metasomatism by LILE-enriched hydrous fluids, derived from subducted oceanic crust in an SSZ setting. Whole-rock analysis of dolerite dykes cutting the peridotite reveals an immobile trace-element composition similar to SSZ-type basalt (Fig. 12c).

Özgül (1984) envisaged the Dipsiz Göl ophiolite as formed by rifting of the Tauride carbonate platform in Late Cretaceous time, for which we have not found supporting evidence. Instead, the available geochemical data from the peridotite thrust sheets are consistent with genesis in an intra-oceanic SSZ setting, as for other 'depleted' Neotethyan peridotites (e.g. Oman, Troodos, Pearce et al. 1984; Lycian Peridotite thrust sheet, Collins \& Robertson 1998). Alternative models for SSZ ophiolites include collapsed spreading ridges, incipient subduction zones and forearc-back-arc settings (Dilek et al. 1998; Robertson 2002). Thus the chemical data must be treated with caution in tectonic synthesis.

\section{Triassic slope facies: Korualan Group}

This unit, known only in the Bozkir area (Figs. 2 and 8a) at the base of the Beyșehir Nappes, is interpreted as a Triassic slope to base-of-slope unit adjacent to a carbonate platform. Pelagic conditions were established by latest Triassic time. The Korualan Group was possibly tectonically cut out in other areas during emplacement. 


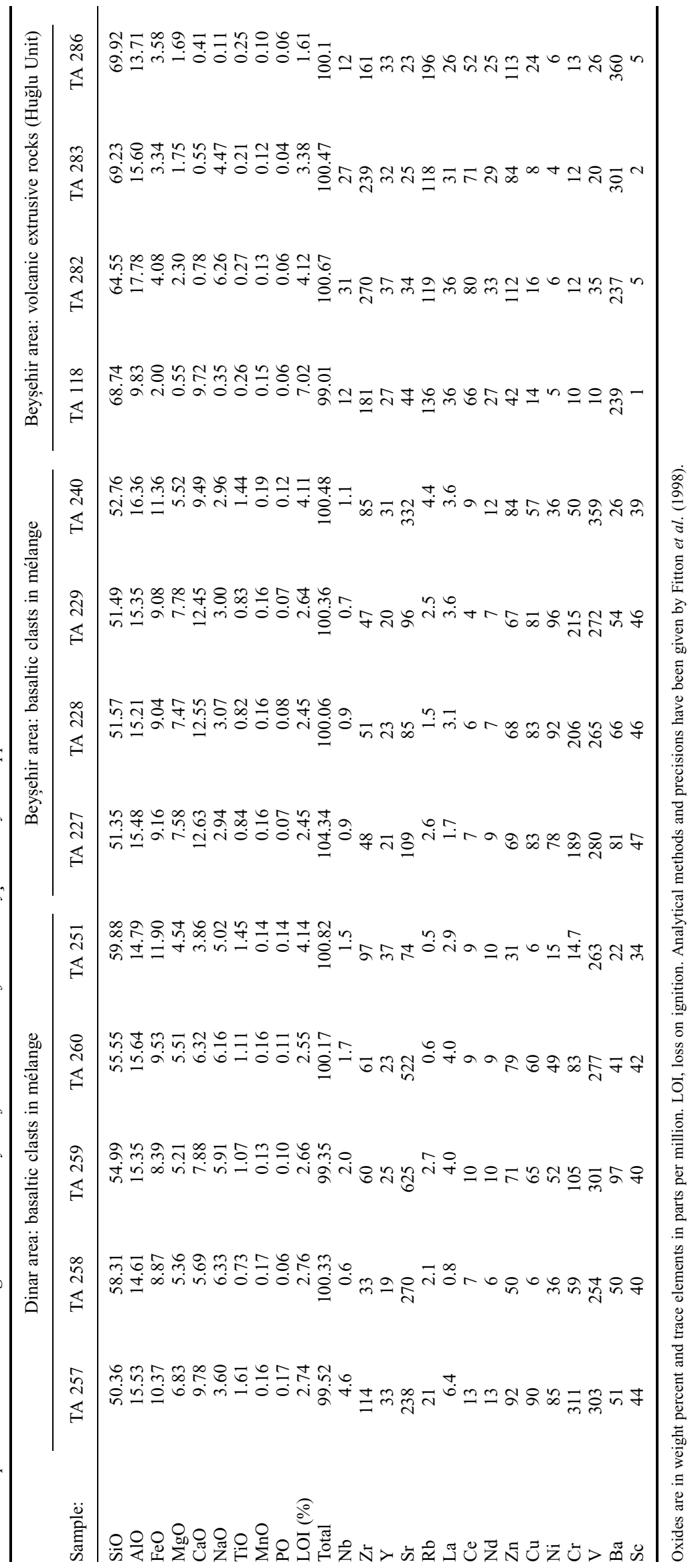



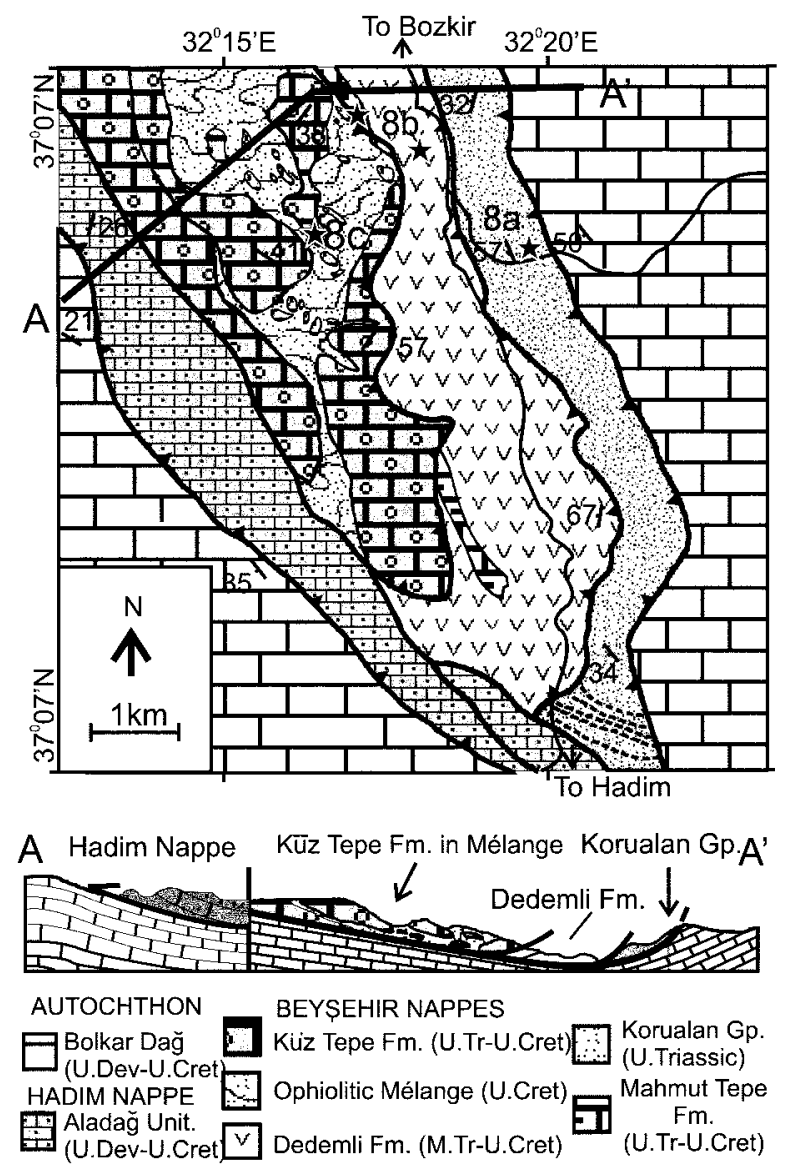

Fig. 7. Geological map and cross-section of the Beyșehir-Hoyran Nappes to the south of Bozkir.

\section{Triassic volcanogenic rift unit and pelagic cover: Huğlu- type units}

This tectonic unit is at a structurally lower position in the Bozkir and Ermenek-Karaman areas than in the Beyșehir area (Fig. 2). The lower, siliciclastic turbidites (e.g. Ermenek area) are indicative of a basinal setting within a continental rift that was inundated by volcanic rocks during Late Triassic time. The intermediate-acidic nature of the volcanic rocks may reflect melting of underlying continental crust undergoing low extension. The rifting was followed by post-rift subsidence and pelagic carbonate deposition at, or near, the calcite compensation depth (CCD) until Late Cretaceous time. Radiolarian chert accumulated in the more basinal areas (e.g. Ermenek-Karaman).

\section{Triassic neritic carbonate and condensed pelagic cover: Boyali Tepe-type units}

We interpret these successions as a more distal, Triassic carbonate platform removed from a continental source, as shown by the absence of siliciclastic sediment. Later, in Toarcian time, the carbonate platform was overlain by deeper-water Ammonitico Rosso condensed pelagic carbonates. Ribbon radiolarites then accumulated in Late Jurassic to Early Cretaceous time (T. Danelian, pers. comm.), followed by Late Cretaceous pelagic carbonates. Initial subduction-accretion gave rise to mélange and broken formation, including ophiolite-derived clastic sediments and material redeposited from underlying successions (chert breccia) set in a matrix including Maastrichtian pelagic carbonate.

\section{Deformation phases}

Initial compression took place in latest Cretaceous time, associated with emplacement of the ophiolite. This was dismembered and emplaced above an inferred accretionary prism, represented by the Ophiolitic Mélange, in Maastrichtian time. The structurally higher volcanogenic and neritic units were also tectonically assembled in latest Cretaceous time. The oceanic crust was emplaced onto the submerged Hadim, Bolkar and Sandikli platform units, whereas the Geyik Dağ platform was still well to the south and escaped this emplacement.

A second phase of emplacement was marked by collapse of the Taurus autochthon (Geyik Dağ) as a foredeep, accumulating Lower-Middle Eocene siliciclastic turbidites and then debris flows, finally overthrust by the Hadim Nappe (where present) and higher units. The Geyik Dağ is internally imbricated with 'corridors' of Middle Eocene siliciclastic turbidites underlying individual thrust imbricates (Özgül 1976; Monod 1977). The provenance of the siliciclastic sediment was probably from the basement of the overriding Hadim Nappe. Where the Hadim Nappe is absent in the west (Dinar area) the foredeep at the top of the Sandikli autochthonous carbonate platform succession contains Eocene large foraminifera (Nummulites), siliciclastic turbidites, debris flows and slumps (Fig. 4a).

\section{Kinematic evidence}

Kinematic data from shear zones between the thrust sheets were measured to infer the direction of emplacement. The base of the thrust sheets is well exposed SW of the Beyșehir area. A roadside cutting and quarry north of Derebucak (Fig. 5) reveals an extensive basal shear zone, c. $20 \mathrm{~m}$ thick, developed in coarse, heterogeneous debris flow deposits derived from the overriding thrust sheets. Brittle-shear fabrics (e.g. thrust-horse geometry, slickensides) indicate a top-to-the-SW sense of movement. Poles to the shear fabrics and slickenline data, when plotted on stereographic projections, indicate vergence to the SW with some scatter mainly to the south (Fig. 15a). Fold data from units within the nappes as a whole suggest a more westerly vergence, but are consistent with overall tectonic transport to the SW (Fig. 15a). In addition, brittle-shear indicators (i.e. slickenlines) and fold vergences from units within the thrust sheets in the Ermenek area (Fig. 15b) indicate a southwesterly transport direction.

Regional palaeomagnetic data suggest that the western area (at least) has undergone post-Eocene $40^{\circ}$ clockwise rotation as part of the eastern limb of the Isparta Angle (Kissel et al. 1993; Tatar et al. 2000). Taking this into account, an overall southerly transport direction for the nappes is implied. The minimum displacement is from the northern edge of the platform to the present outcrop, c. $150 \mathrm{~km}$.

\section{Discussion of regional palaeogeography}

The Beyșehir-Hoyran-Hadim Nappes can be restored to several alternative positions within the Northern Neotethys (Fig. 17) assuming either in-sequence (Fig. 16a) or out-of-sequence thrusting (Fig. 16b).

In Fig. 17a the Geyik Dağ, Sandikli Unit, Bolkar Dağ and Hadim Nappe formed an east-west-trending southerly continental margin. The Kirșehir-Niğde massif formed a promontory of this continental margin (Göncüoglü et al. 1996-1997). Assuming 


\section{Middle thrust sheet}

\section{Lowest thrust sheet}

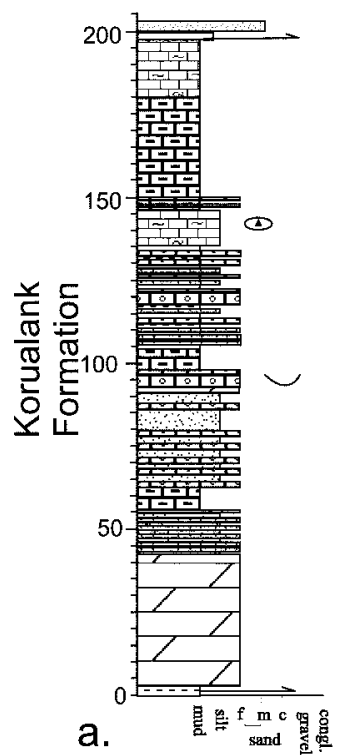

Siliceous pelagic Ist. 鹿 Redeposited Ist.

\section{Shale}

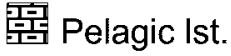

$\triangle$ Dolomite

$\checkmark$ Bivalve fragments

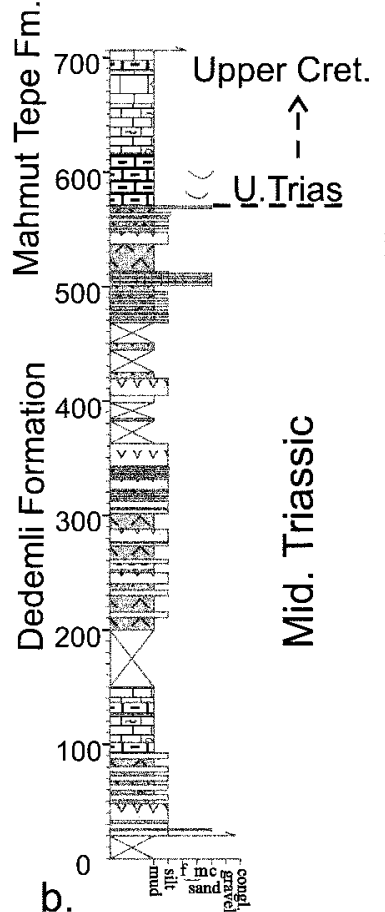

Highest thrust sheet

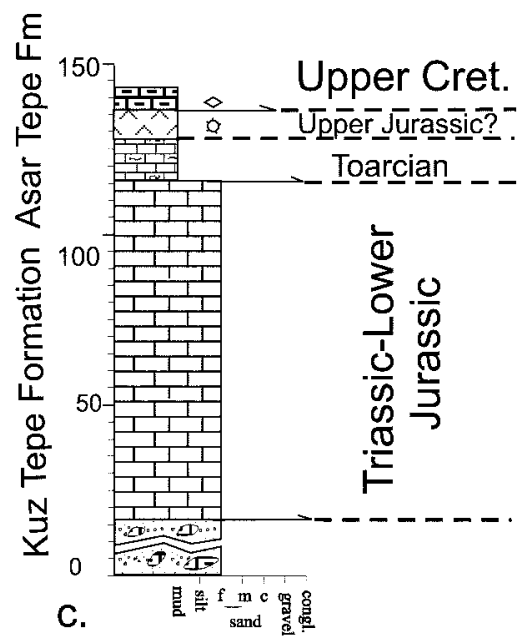

焉 Platy Lst.

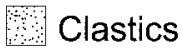

踁 Pink pelagic Lst+chert.

Volc.clastic

Sava

¿. Tuff

\section{Radiolarian chert}

Nodular Lst.

Neritic limestone

- Aph Ophiolitic Mélange

\section{Radiolaria $\diamond$ Globotruncana $\propto$ Chert nodules}

Fig. 8. Measured sedimentary logs of the Beyșehir-Hoyran units in the Bozkir area. (See Fig. 7 for location of logs.)

the in-sequence thrusting model (Fig. 16a), the conjugate of this margin is in the Pontides (Ustaömer \& Robertson 1997; Y1lmaz et al. 1997). The main problem is that the Pontide and Anatolide-Tauride margin evolution are dissimilar, e.g. with the major latest Triassic 'Cimmerian' orogenic event being restricted to the Pontide margin, whereas Triassic rifting and Jurassic passive margin subsidence continued on the Anatolide-Tauride margin without a comparable major orogenic event (Robertson \& Pickett 2000). Assuming the out-of-sequence thrusting model, a rifted continental fragment would border the Anatolide-Tauride platform (Fig. 17b).

In Fig. $17 \mathrm{~b}$ the Northern Neotethys was split into two branches, a main northerly oceanic strand and a southerly strand, termed the Inner Tauride Ocean, which split off a KirșehirNiğde microcontinent (Șengör \& Yılmaz 1981; Görür et al. 1984). The Beysehir-Hoyran upper thrust sheets again fringed the Anatolide-Tauride continental margin as in the out-ofsequence thrust model. The Beyșehir-Hoyran ophiolites formed at a spreading centre within the Inner Tauride Ocean. Assuming the in-sequence thrust model (Fig. 16b), the upper nappes could restore effectively as a westward extension of the Kirşehir-Niğde microcontinent (or satellite platforms).
Additional evidence from the Izmir-Ankara-Erzincan suture zone to the north of the study area is needed to test fully the concept of an Inner Tauride ocean (Okay et al. 2001). However, the extraordinary lateral continuity of the Beysehir-Hoyran Nappes over c. $700 \mathrm{~km}$, extending far to the SE of the KirșehirNiğde Massif, is consistent with the former existence of an Inner Tauride ocean, rather than requiring the nappes to be thrust $>500 \mathrm{~km}$ from the Ankara-Erzincan suture zone north of the Kirșehir Massif.

We infer that the southern margin of the Northern Neoteothys was palaeogeographically irregular, with the Dinar units in the west being located in an embayment between the Geyik DağHadim platform to the east and the Menderes-Bey Dağları platform to the west. The Dinar units perhaps connected southward palaeogeographically through the Isparta Angle to the Southerly Neotethys (Robertson 1993).

In our favoured out-of-sequence thrust interpretation (Figs. $16 \mathrm{~b}$ and $17 \mathrm{~b}$ ) the ophiolites were emplaced southwards along the length of the Anatolide-Tauride continental margin in latest Cretaceous (Campanian-Maastrichtian) time. Initial emplacement of a SSZ-type ophiolite onto the continental margin was followed by rethrusting of the accreted units and the ophiolite 


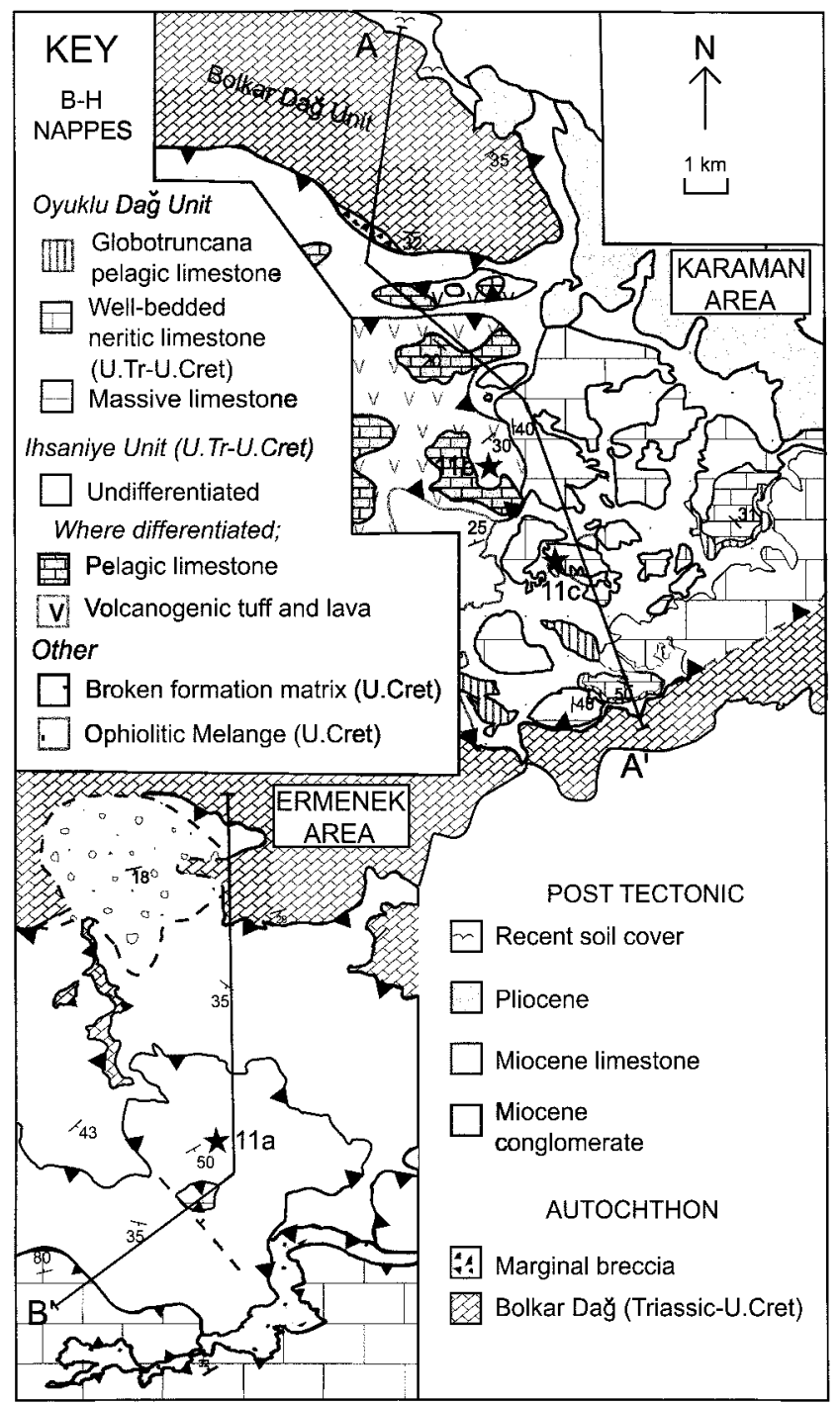

Fig. 9. Geological map of the Beysehir-Hoyran Nappes in the Karaman-Ermenek area (modified from Koçyiğit 1976; Gökdeniz 1981). during late Maastrichtian time. During Late Eocene time, related to suture tightening and regional final closure of the Northern Neotethys, the former carbonate platform edge was detatched and thrust southwards as the Hadim Nappe and Bolkar Dağ Unit together with their cover of previously assembled allochthonous units. Further west, sited in a former palaeogeographical embayment, the Late Cretaceous Dinar thrust sheets were merely rethrust some distance further south over the relatively autochthonous carbonate platform without detaching large carbonate platform slices. The Late Eocene thrusting possibly relates to 'hard collision' that accompanied regional suturing of the Northern Neotethys. The presence of an Oligo-Miocene unconformable cover of the Dinar units shows that this deformation was soon over, whereas, by contrast, a similar southward rethrusting of the Lycian Nappes, beginning in Late Eocene time (Collins \& Robertson 1998) was not completed until Late Miocene time (Poisson 1977).

\section{Conclusions}

Assuming our favoured out-of-sequence thrust model, we infer the following tectonostratigraphic events.

(1) The northern margin of Gondwana rifted in Triassic time, as represented by the autochthonous Taurus carbonate platform and the Hadim Nappe. Siliciclastic and carbonate turbidites accumulated in proximal slope settings (Korualan Group; Bozkir area). Bordering rift siliciclastic rocks and minor calc-turbidites (e.g lower Ihsaniye Unit, Ermenek area) were inundated with intermediate-silicic composition volcanic rocks, volcaniclastic rocks and tuff, which accumulated in a deep-water basin undergoing background radiolarian hemipelagic sedimentation. Neritic carbonate platforms developed in a generally more outboard setting (e.g. Boyali-Tepe Unit; Beyșehir area). Platforms and basinal units varied in scale and palaeogeographical location from west to east.

(2) Rifting ended in Late Triassic time and was followed by post-rift subsidence. Pelagic deposition persisted in rift basins (e.g. Huğlu Unit; Beyșehir area), whereas neritic platforms subsided in Early-Mid Jurassic time and were covered by calcareous pelagic sediments (including Ammonitico Rosso),
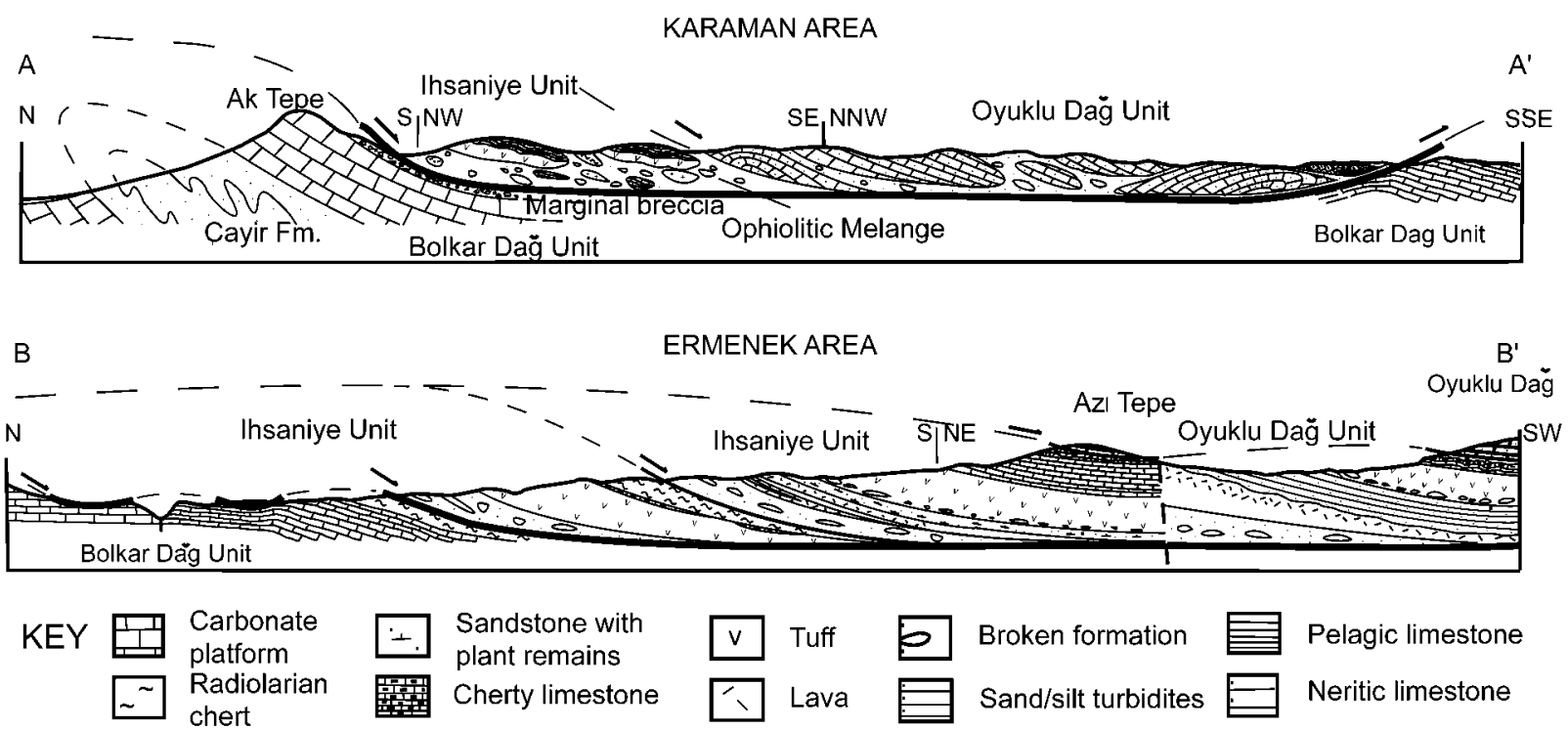

Broken formation

Pelagic limestone

Sand/silt turbidites

Neritic limestone

Fig. 10. Cross-section of the Beyșehir-Hoyran Nappes in the Karaman-Ermenek area. 


\section{Ihsaniye Unit: Ermenek}

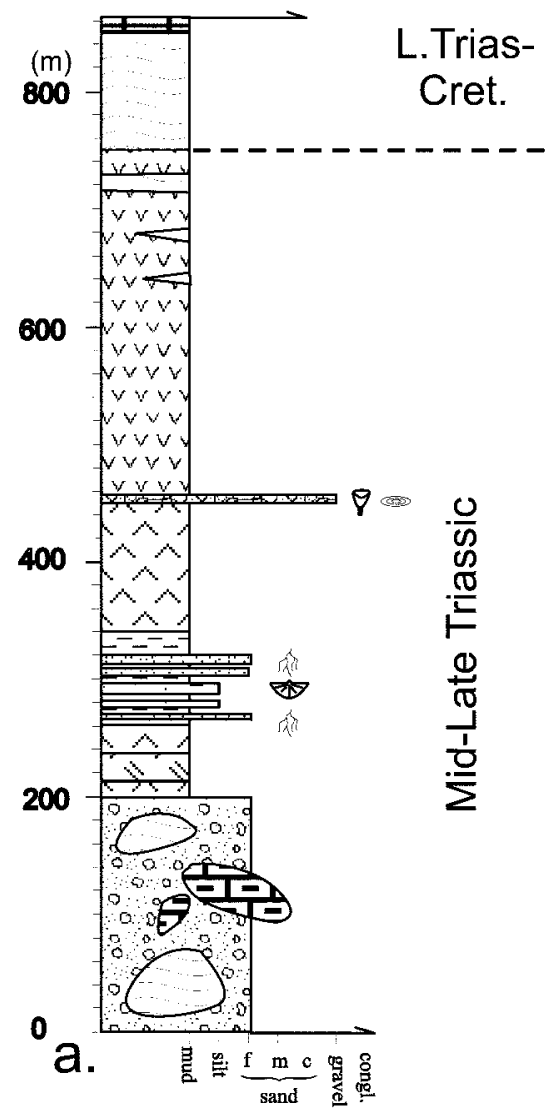

Ihsaniye Unit: Karaman

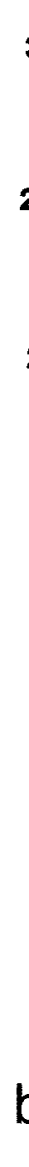

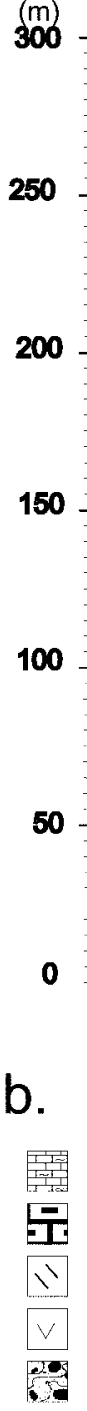

50
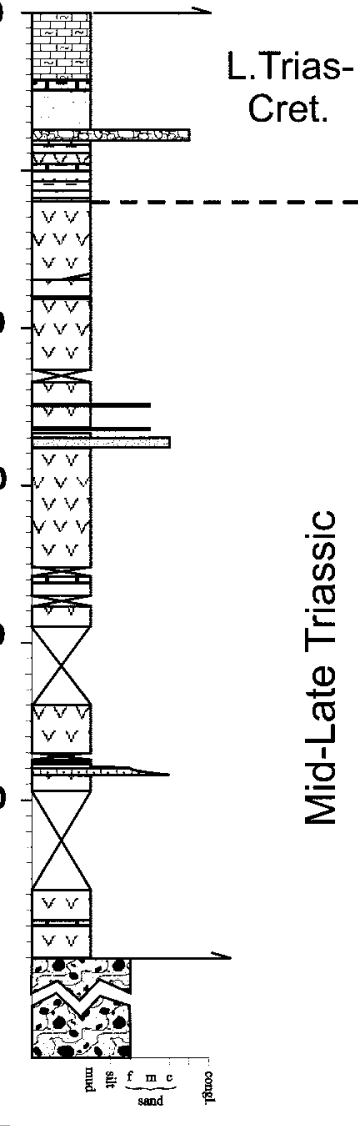

Oyuklu Dağ Unit: Karaman
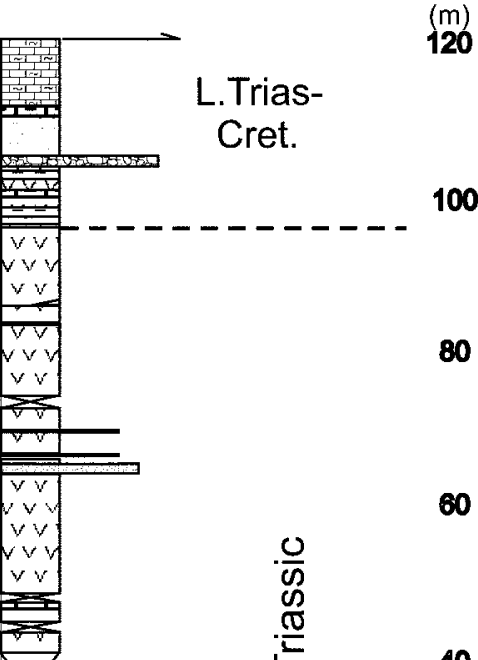

Cherty Lst. a Radiolaria

C.

120
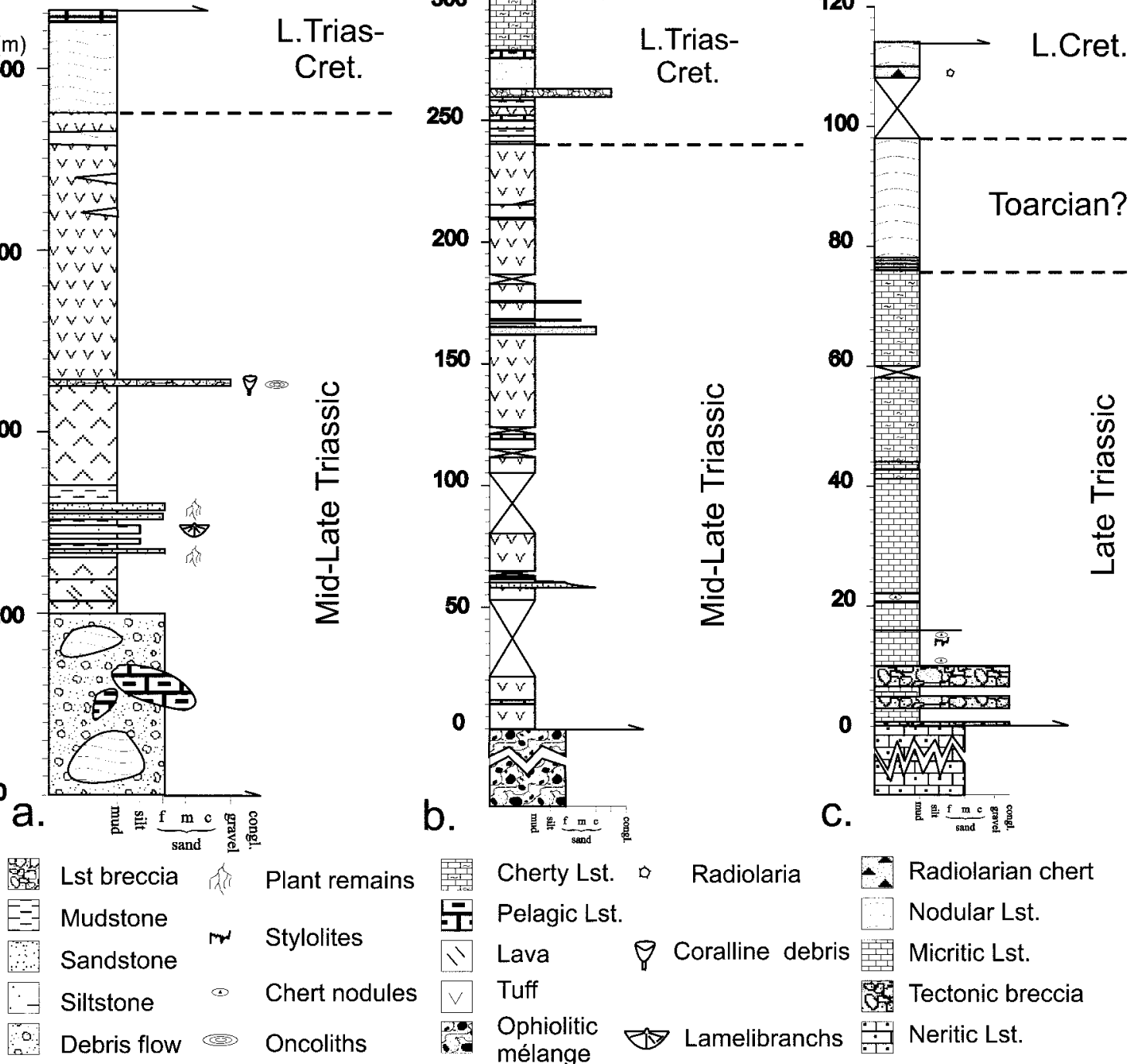

Pelagic Lst.

Lava

Tuff

Ophiolitic mélange

\section{Coralline debris}

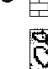

Lamelibranchs Neritic Lst.

Fig. 11. Measured log of the Beyșehir-Hoyran units in the Karaman-Ermenek area. (See Fig. 9 for location of logs.)

above the CCD. Nodular radiolarian chert accumulated during Late Jurassic-Early Cretaceous time.

(3) The ophiolite was generated above a north-dipping intraoceanic subduction zone probably in Late Cretaceous time. The amphibolite-facies metamorphic sole (Beyșehir area) was formed by underplating of oceanic crust beneath young hot suprasubduction zone lithosphere.

(4) The within-plate basalt and MORB-type volcanic blocks within the Ophiolitic Mélange, together with radiolarian chert, pelagic carbonates and volcanogenic sediments represent a Late Cretaceous subduction-accretionary complex related to northward subduction of Neotethys.

(5) Tectonic disruption of the higher Beysehir-Hoyran Nappes within Late Cretaceous (Maastrichtian) ophiolite-derived matrix resulted from collision and accretion of the Tauride continental margin with the north-dipping subduction zone.

(6) During latest Cretaceous time the accretionary prism and SSZ ophiolite were emplaced southwards onto the northern edge of the Tauride carbonate platform (future Hadim Nappe), whereas platform deposition continued on the Tauride platform, c. $150 \mathrm{~km}$ further south.

(7) Erosion of the emplaced ophiolite probably took place in Paleocene times, although no trace of a cover sequence remains, unlike the Lycian Nappes.

(8) During Early Tertiary time any remaining Northern Neotethyan oceanic crust was subducted, leading to final collision of the Tauride continental unit with the Eurasian margin during Late Eocene time. During Late Eocene collision, the Palaeozoic-Early Tertiary successions were detatched as the Hadim Nappe and Bolkar Dağ Unit and were thrust up to $150 \mathrm{~km}$ southward over an Early-Mid-Eocene siliciclastic foredeep, with the previously assembled (Upper Cretaceous) nappe stack riding above. Further west (Dinar area), the regional platform remained in situ and the Upper Cretaceous Ophiolitic Mélange and ophiolite were thrust onto the Eocene siliciclastic foredeep, resulting in interlayering of mélange units of latest Cretaceous and Early Tertiary age.

(9) After collision, the Beyșehir-Hoyran Nappes underwent 


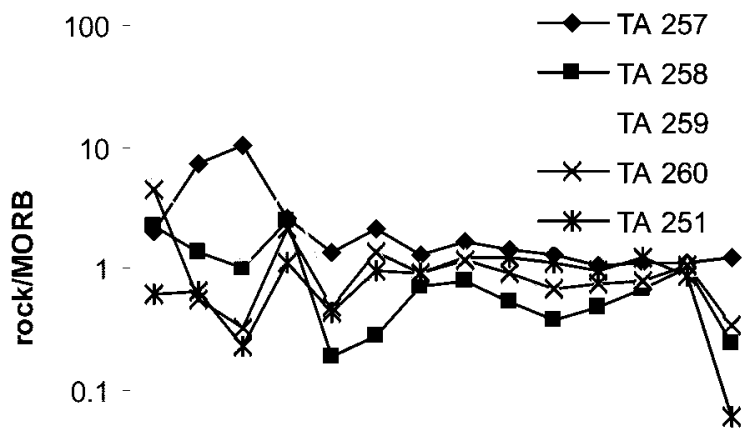

0.01

a. $\mathrm{Sr} K \mathrm{Rb} B \mathrm{Ba} \mathrm{Nb} \mathrm{LeNd} \mathrm{P} \mathrm{Zr}$ Ti $\mathrm{Y}$ Sc $\mathrm{Cr}$

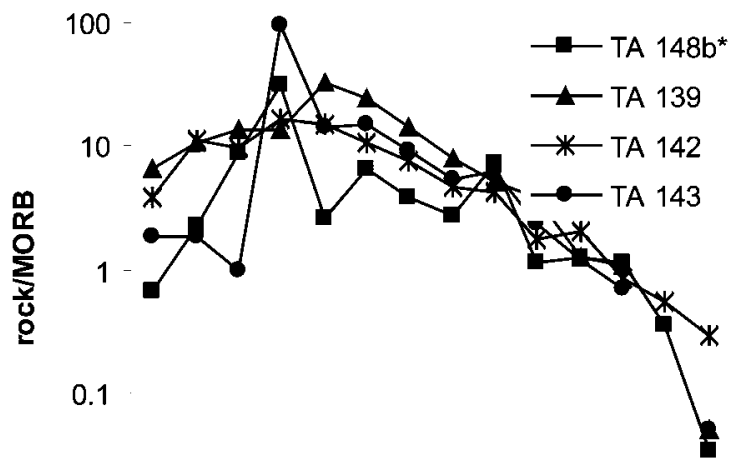

b. $\mathrm{Sr} K \mathrm{Rb}$ Ba Nb La Ce Nd P $\mathrm{Zr} \mathrm{Ti}$ Y Sc $\mathrm{Cr}$

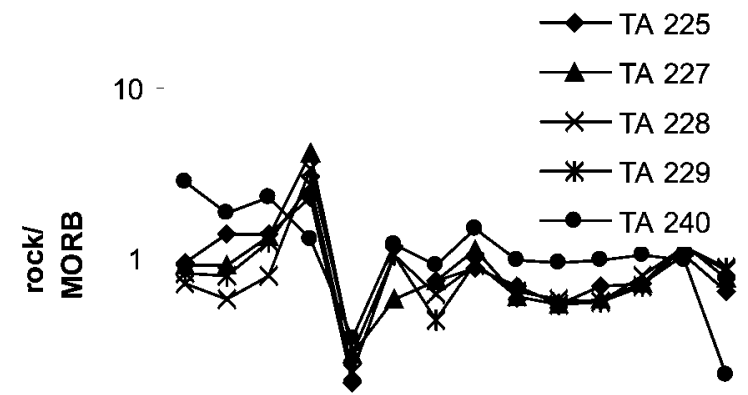

0.1

C. $\mathrm{Sr} K \mathrm{Rb} \mathrm{Ba} \mathrm{Nb} \mathrm{La} \mathrm{CeNd} \mathrm{P} \mathrm{Zr} \mathrm{Ti}$ Y Sc Cr

Fig. 12. Mid-ocean ridge basalt (MORB)-normalized incompatible element plots of selected basalt clasts within the Ophiolitic Mélange (normalizing values from Pearce 1983). (a) Dinar area; (b) Beyșehir area; (c) dolerite dykes cutting Kızıldağ ophiolite north of Lake Beyșehir (Șarkikaraağaç).

Miocene and younger extensional tectonics (e.g. east of Bozkir area-Dinar area) and clockwise palaeotectonic rotation.

T.A. thanks NERC for financial support by way of a research studentship (grant GT04/98/81/ES). The University of Edinburgh assisted A.H.F.R. with fieldwork costs. We thank M. Clark and J. E. Dixon for discussion. O. Monod kindly drew our attention to additional literature. Ü. Ünlügenç is thanked for logistical support and scientific discussion. The manuscript

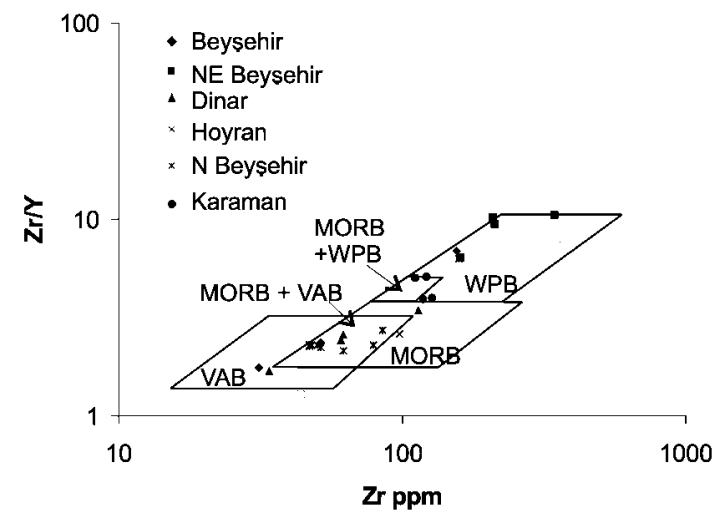

Fig. 13. $\mathrm{Zr}$ v. $\mathrm{Zr} / \mathrm{Y}$ diagram (Pearce \& Norry 1979) of selected basalt clasts within the Ophiolitic Mélange. MORB, mid-ocean ridge basalt; WPB, within-plate basalt; VAB, volcanic arc basalt.
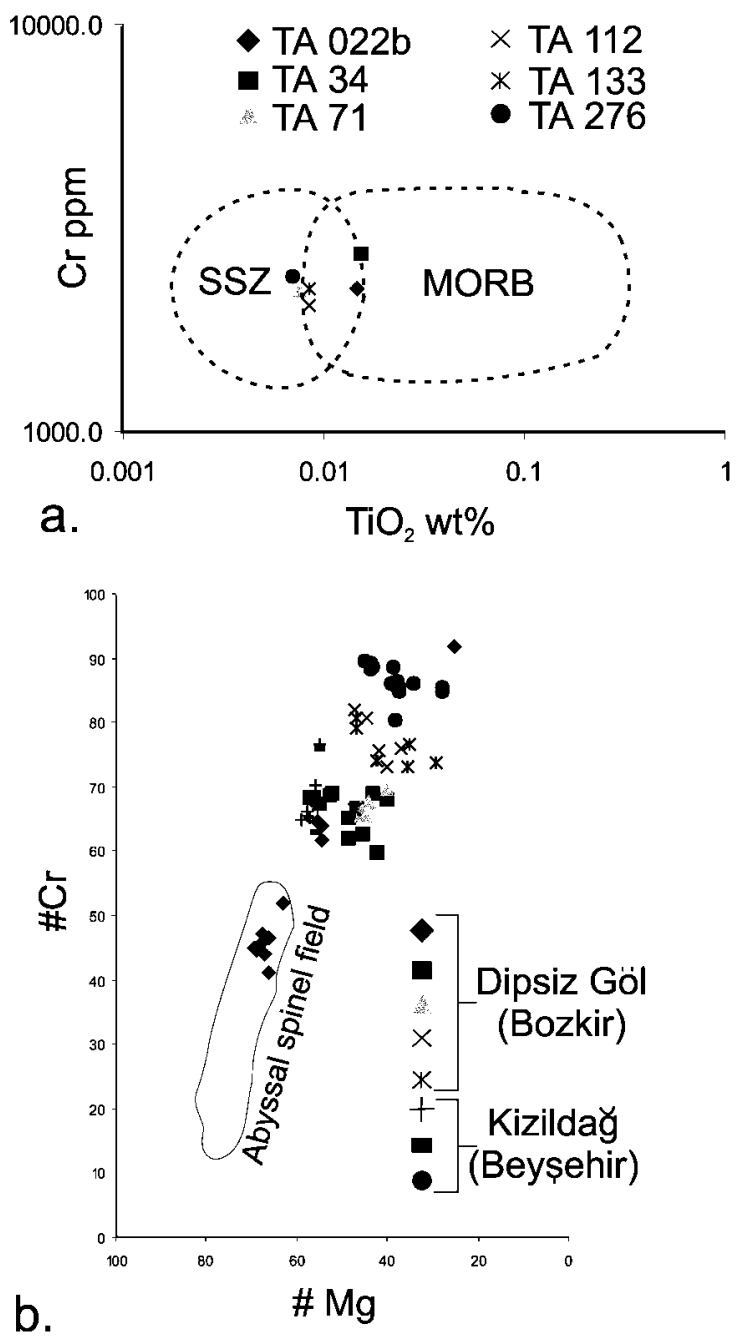

Fig. 14. (a) $\mathrm{TiO}_{2}$ wt $\%$ v. $\mathrm{Cr}$ ppm whole-rock compositions of fresh peridotite from the Kızıldağ (Beyșehir) ophiolite (Pearce et al. 1984). (b) Chrome spinel compositions from peridotite of the Dipsiz Göl and Kızıldağ (Beyșehir) ophiolites, plotted on an Mg-number v. Cr-number diagram (Dick \& Bullen 1984). Chrome spinels analysed on a Cameca Camebax electron microprobe at the University of Edinburgh, operated at a $20 \mathrm{kV}$ accelerating potential and a beam current of $20 \mu \mathrm{m}$. 


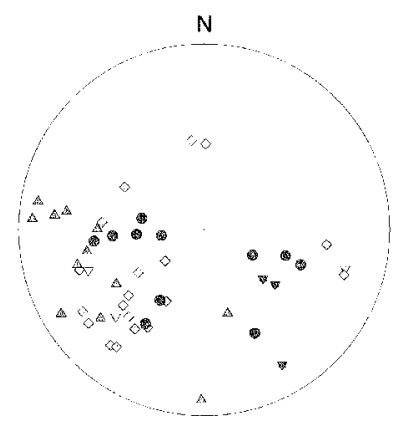

a)

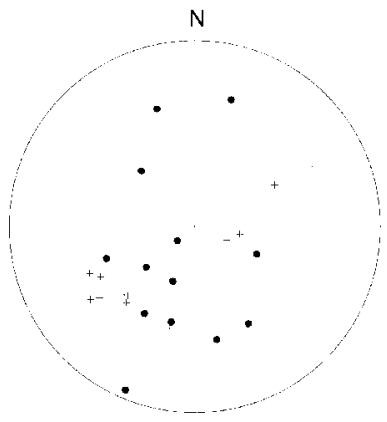

b)
Fig. 15. (a) Equal-area lower hemisphere projection showing kinematic data from Beyșehir area. Down-facing triangles, poles to shear fabric (Derebucak); diamonds, slickenline lineations (Derebucak); up-facing triangles, fold data (throughout Beyșehir-Hoyran Nappes); circles, poles to shear fabric (Üzümlü); filled down-facing triangles, fold data (Üzümlü). (b) Equal-area lower hemisphere projection showing kinematic data from Ermenek area. Readings come from exposures throughout the thrust sheets. $\bullet$, fold data; + , slickenline lineations. greatly benefited from comments by A. Poisson, A. Okay, S. Matthews and an anonymous reviewer.

\section{References}

Blumenthal, M. 1947. Geologie der Taurusketten im hinterland von Seydisehir und Beyşehir. Maden Tetkik ve Arama Report D 2.

Blumenthal, M. 1951. Récherches géologiques dans les Taurus occidental dans l'arrière-pays d'Alanya. Maden Tetkik ve Arama Report D 5.

Blumenthal, M. 1956. Les châ̂nes bordières du Taurus au sud-ouest du bassin de Karaman-Konya et le problème stratigraphique de la formation schistoradiolaritique. Bulletin of Maden Tetkik ve Arama, 48, 1-39.

Blumenthal, M. 1960-1963. Le Système structural du Taurus sud-anatolien. Livre Mémoire. P. Fallot, Paris, 611-662.

Collins, A. \& Robertson, A.H.F. 1998. Processes of Late Cretaceous to Late Miocene episodic thrust-sheet translation in the Lycian Taurides, southwest Turkey. Journal of the Geological Society, London, 155, 759-772.

DeAn, W.T. \& ÖzGüL, N. 1994. Cambrian rocks and faunas, Hudai area, Taurus Mountains, southeastern Turkey. Bulletin Institut Royal des Sciences Naturelles de Belgique, Sciences de la Terre, 64, 1-16.

Degnan, P. \& Robertson, A.H.F. 1998. Mesozoic-Tertiary deep-water passive margin sedimentation, Pindos Zone, southern Greece. Sedimentary Geology, 117, 33-70

Demirkol, C. 1984. Sultanda kuzeybatısının jeolojisi ve Beyșehir-Hoyran Napları

\section{(a) In-sequence thrusting}
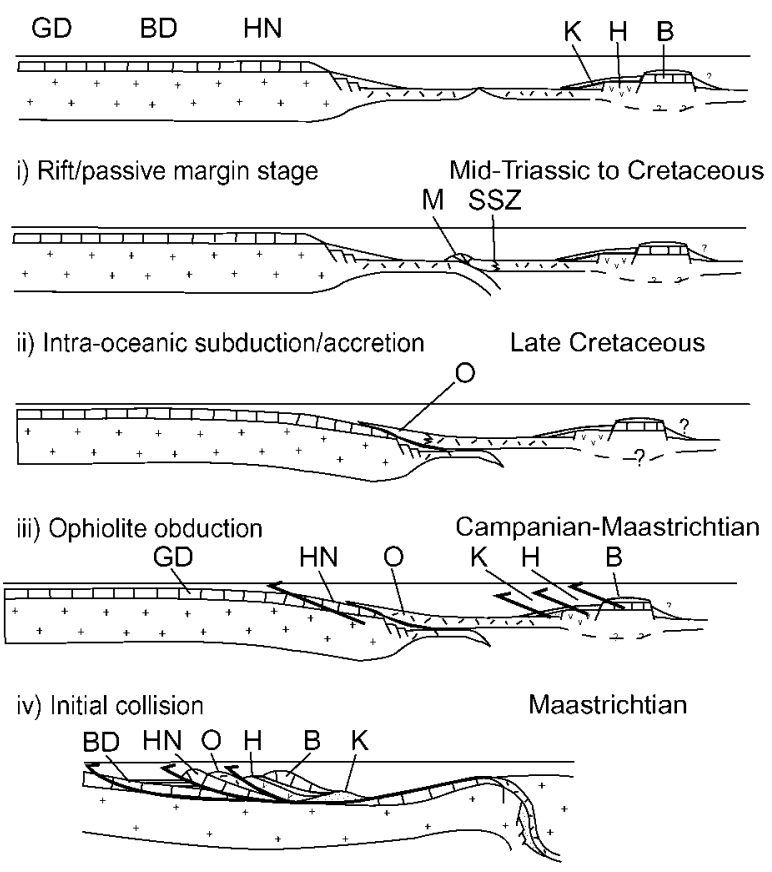

v) Continental collision/nappe emplacement Late Eocene

\section{(b) Out-of-sequence thrusting}
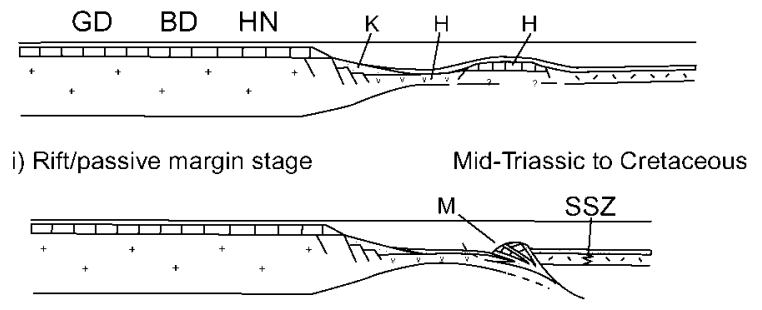

ii) Intra-oceanic subduction/accretion Late Cretaceous

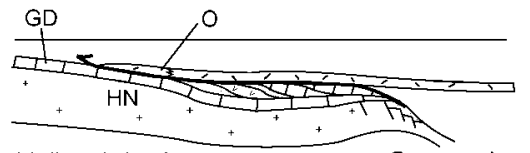

ii) Ophiolite obduction Campanian-Maastrichtian

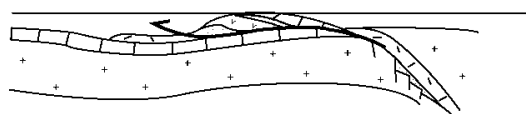

iv) Initial collision Maastrichtian

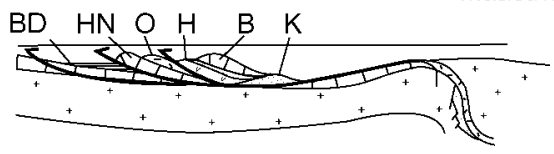

v) Continental collision/nappe emplacement Late Eocene

\section{BD-Bolkar Dağ Unit GD- Geyik Dağ Unit HN- Hadim Nappe \\ O- Ophiolite \\ M- Melange}

SSZ- Supra subduction spreading

K- Korualan slope unit

$\mathrm{H}$ - Huğlu-type volcano sedimentary unit

B- Boyali Tepe-type subsided platform unit

Fig. 16. Reconstructed tectonic settings assuming (a) in-sequence thrusting, (b) out-of-sequence thrusting. (a) Rifts separated the southern Tauride carbonate platform and off-margin fragment. After SSZ ophiolite genesis, the ophiolite and off-margin units were emplaced onto the continental margin in Maastrichtian time. During Late Eocene suturing and tightening the former platform margin was detatched and thrust southwards, carrying the previously assembled thrust stack passively above. (b) As (a), but the spreading centre developed northwards of the rifted carbonate platform. SSZ ophiolite genesis was followed by accretion of platform-basinal units beneath the overriding ophiolite, which was emplaced over the carbonate platform (Geyik Dağ). During collision the accreted units were rethrust above the ophiolite. Rethrusting in Late Eocene time occurred as in (a). 
a.)

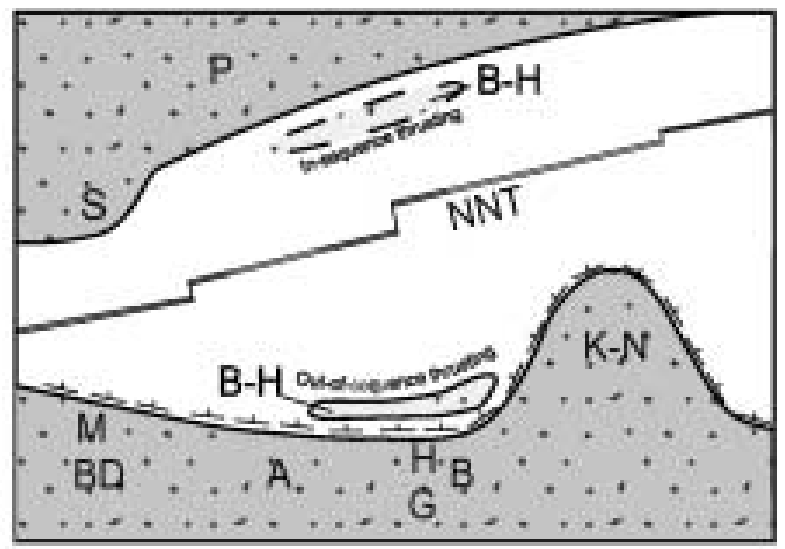

b.)

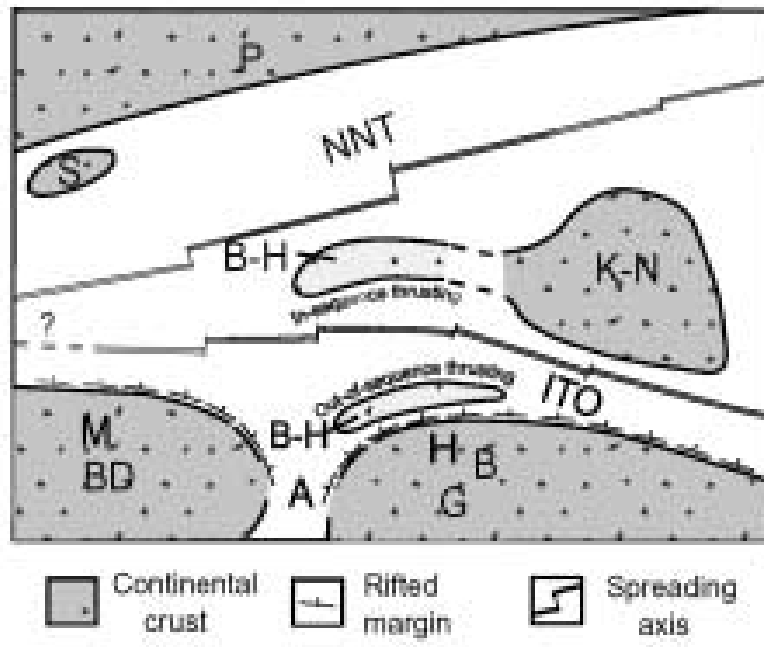

K-N-Krsehir-Nigde Massif M-Menderes Massif NNT- Northerly Neotettrys P-Pontides spreading axis

S-Sakarya Unit

Fig. 17. Palaeogeographical sketch maps of the Northern Neotethys during Mid-Jurassic time. (a) Single Northern Neotethys with promontories. North and south alternative settings of the BeysehirHoyran Nappes according to in-sequence or out-of-sequence thrusting (Fig. 16). (b) Northern Neotethys with microcontinents and again possible alternative settings of the Beyșehir-Hoyran Nappes. The model shown in (b) with southerly location of nappes is preferred. (Note, in (b), spreading possibly jumped northwards, isolating the Kirșehir-Niğde microcontinent from the Anatolide-Tauride platform.)

ile ilişkileri. Maden Tektik ve Arama Report, Project TBAG-382.

Dercourt, J., Ricou, L.E. \& Vrielynck, B. (eds) 1992. Atlas Tethys Paleoenvironmental Maps. Beicip-Franlab.

Dercourt, J., Zonenshain, L.P., Ricou, L.E. \& 16 others 1986. Geological evolution of the Tethys belt from the Atlantic to the Pamirs since the Lias. Tectonophysics, 123, 241-315.

Dick, H.J.B. \& Bullen, T. 1984. Chromian spinel as a petrographic indicator in abyssal and alpine-type peridotites and spatially associated lavas. Contributions to Mineralogy and Petrology, 86, 54-76.

Dilek, Y., Moores, E., Elthon, D. \& Nicolas, A. (eds) 1998. Ophiolites and Oceanic Crust. Geological Society of America, Special Paper, 349.

EцIToK, Ö. 2000. Sarkikaraağaç (Isparta) ve Gevresinin Jeoloji, Mineraloji ve Petrografisi. PhD thesis, Süleyman Demirel University, Isparta, Turkey.

Fitton, J.G., Saunders, A.D., Larsen, L.M., Hardarson, B.S. \& Norry, M.J. 1998. Volcanic rocks from the East Greenland margin at $63^{\circ} \mathrm{N}$ : composition,

petrogenesis and mantle sources. In: SAUnders, A.D., Larsen, H.C. \& WiSE, S.H. Proceedings of the Ocean Drilling Program, Scientific Results, 152. Ocean Drilling Program, College Station, TX, 331-350.

FleurRY, J.J. 1980. Evolution d'une Platforme et d'un Bassin dans leur Cadre alpin: les Zones de Gavrovo-Tripolitza et du Pinde-Olonos. Societé Géologique du Nord, Special Publication, 4.

GöKDENIZ, S. 1981. Récherches géologique dans les Taurus occidental entre Karaman et Ermenek. Les Series à Tuffites vertes Triasiques. $\mathrm{PhD}$ thesis, Université de Paris-Sud, Orsay.

GönCÜoĞLÜ, C.M., DireK, K. \& Kozlu, H. 1996-1997. Pre-alpine and alpine terranes in Turkey: explanatory notes to the terrane map of Turkey. Annales Géologique de Pays Héllenique, 37, 1-3.

GöNCÜoĞLU, M.C. 2001. Geology of the Late Pre-Cambrian rocks in the Sandıklı area: implications for the Pan-African evolution in NW Gondwana. Conference Abstracts, 4th International Symposium on Eastern Mediterranean Geology, Isparta.

GöncüoĞLU, M.C. \& Kozlu, H. 2000. Early Paleozoic evolution of the NW Gondwanaland: data from Southern Turkey and surrounding regions. Gondwana Research, 3, 315-324.

GörÜr, N., OKtaY, F.Y., Seymen, I. \& S engör, A.M.C. 1984. Paleotectonic evolution of Tuz Gölü Basin complex, central Turkey. In: Dixon, J.E. \& Robertson, A.H.F. The Geological Evolution of the Eastern Mediterranean. Geological Society, London, Special Publications, 17, 81-96.

Gutnic, M. 1977. Géologie du Taurus Pisidian au Nord D'Isparta (Turquie). PhD thesis, Université de Paris-Sud, Orsay.

Gutnic, M., Kelter, D. \& Monod, O. 1968. Découverte de nappes de charriage dans le Nord de Taurus occidental (Turquie). Comptes Rendus de l'Académie des Sciences, Série D, 266, 988-991.

Gutnic, M., Monod, O., Poisson, A. \& Dumont, J.-F. 1979. Géologie des Taurides Occidentales (Turquie). Mémoires de la Société Géologique de France, 137, 1-112.

Haude, H. 1969. Stratigraphie ünd Tektonik des südlichen Sultan-Dağ (SWAnatolien). Zeitschrift der Deutschen Geologischen Gesellschaft, 123, $411-421$.

Kissel, C., Averbuch, O., Delamotte, D.F., Monod, O. \& Allerton, S. 1993. First palaeomagnetic evidence for a post-Eocene clockwise rotation of the western Taurides thrust belt east of the Isparta reentrant (southwestern Turkey). Earth and Planetary Science Letters, 112, 1-2.

KoçYIĞIT, A. 1976. Karaman-Ermenek (Konya) bölgesinde ofiyolitli melanj ve diğer olușuklar. Geological Society of Turkey Bulletin, 19, 103-115.

Maden Tektik ve Arama Genel Müdürlü ĞÜ, 1997. 1:20,000 Turkish Geological Map, No. 4, Isparta Sheet. Maden Tetkik ve Arama, Ankara.

Mascle, A. \& Moore, J.C. ET AL. 1990. ODP Leg 110: tectonic and hydrologic synthesis. In: Moore, J.C. \& Mascle, A. Proceeding of the Ocean Drilling Program, Scientific Results, 110. Ocean Drilling Program, College Station, TX, 409-422.

Monod, O. 1977. Récherches géologique dans les Taurus occidental au sud de Beyșehir (Türquie). $\mathrm{PhD}$ thesis, Université de Paris-Sud, Orsay.

MonoD, O. \& AKAY, E. 1984. Evidence for an Upper Triassic-Early Jurassic orogenic event in the Taurides. In: Dixon, J.E. \& RoberTson, A.H.F. Geological Evolution of the Eastern Mediterranean. Geological Society, London, Special Publications, 17, 113-128.

OKay, A.I., TANSEZ, I. \& TÜysüz, O. 2001. Obduction, subduction and collision as reflected in the Upper Cretaceous-Lower Tertiary sedimentary record of Western Turkey. Geological Magazine, 138, 117-142.

ÖzGüL, N. 1976. Toroslar'in bazi temel jeoloji özellikleri. Geological Society of Turkey Bulletin, 19, 65-78.

ÖZGüL, N. 1984. Stratigraphy and tectonic evolution of the Central Taurides. In: Tekeli, O. \& GöNcüoĞLu, M.C. Proceedings of the International Symposium on the Geology of the Taurus Belt, Ankara. Publ, Town, 77-90.

ÖzGüL, N. 1997. Stratigraphy of the tectonostratigraphical units around HadimBozkir-Tașent region, northern part of the Central Taurides. Bulletin of Mineral Resources Exloration (Turkey), 119, 113-174.

ÖZgüL, N. \& ARPAT, E. 1973. Structural units of the Taurus orogenic belt and their continuation in the neighbouring regions: selection of papers on the Eastern Mediterranean region, presented at the 23rd congress of CIESM in Athens. Bulletin of the Geological Society of Greece, 10-1, 155-164.

Parlak, O., Hoeck, V. \& Delaloye, M. 2000. Supra-subduction zone origin of the Pozanti-Karsanti ophiolite (S. Turkey) deduced from whole rock and mineral chemistry of the gabbro cumulates. In: BOzKURT, E., WiNCHESTER, J.A. \& PIPER, J.D. Tectonics and Magmatism in Turkey and the Surrounding Area. Geological Society, London, Special Publications, 173, 219-234.

Pearce, J.A. 1983. Role of the sub-continental lithosphere in magma genesis at active continental margins. In: HAWKesworth, C.J. \& NORRY, M.J. Continental Basalts and Mantle Xenoliths. Shiva, Nantwich, 230-249.

Pearce, J.A. \& Norry, M.J. 1979. Petrogenic implications of Ti, Zr, Y and Nb variations in volcanic rocks. Contributions to Mineralogy and Petrology, 69, $33-47$. 
Pearce, J.A., Lippard, S.J. \& Roberts, S. 1984. Characteristics and tectonic significance of supra-subduction zone ophiolites. In: KoKelaAR, B.P. \& Howells, M.F. Marginal Basin Geology. Geological Society, London, Special Publications, 16, 77-94.

Poisson, A. 1977. Récherches géologiques dans les Taurides occidentales. PhD thesis, Université de Paris-Sud, Orsay.

Robertson, A.H.F. 1993. Mesozoic-Tertiary sedimentary and tectonic evolution of Neotethyan carbonate platforms, margins and small ocean basins in the Antalya complex, S.W. Turkey. In: Frostick, L.E. \& Steel, R. Tectonic Controls and Signatures in Sedimentary Successions. International Association of Sedimentologists, Special Publications, 20, 415-465.

Robertson, A.H.F. 2002. Overview of the genesis and emplacement of Mesozoic ophiolites in the Eastern Mediterranean Tethyan Region. Lithos Special Issue on Eastern Mediterranean Ophiolites, in press.

Robertson, A.H.F. \& Dixon, J.E. 1984. Introduction: aspects of the geological evolution of the Eastern Mediterranean. In: Dixon, J.E. \& RobERTSON, A.H.F. The Geological Evolution of the Eastern Mediterranean. Geological Society, London, Special Publications, 17, 1-74

Robertson, A.H.F. \& Pickett, E.A. 2000. Palaeozoic-Early Tertiary evolution of melanges, rift and passive margin units in the Karaburun Peninsula (W. Turkey) and Chios Island (Greece). In: Bozkurt, E., Winchester, J.A. \& PIPER, J.D.A. Tectonics and Magmatism in Turkey and the Surrounding Area. Geological Society, London, Special Publications, 173, 423-440.

Searle, M.P., CoOPer, D.J.W. \& Watts, K.F. 1990. Structure of the Jebel Sumeini-Jebel Ghawil area, Northern Oman. In: Robertson, A.H.F., Searle, M.P. \& Ries, A.C. The Geology and Tectonics of the Oman Region. Geological Society, London, Special Publications, 49, 361-374.

Şenel, M., Dalkiltas, H., GediK, I. \& 5 others 1998. Orta Toroslar'da Guzelsu koridoru ve kuzeyinin stratigrafisi. Maden Tetkik ve Arama Report, 120.

ŞENGör, A.M.C. \& Yilmaz, Y. 1981. Tethyan evolution of Turkey; a plate tectonic approach. Tectonophysics, 75, 181-241.

Smith, A.G., Woodcock, N.H. \& NAYLOR, M.A. 1979. The structural evolution of the Mesozoic continental margin, Othris Mountains, Greece. Journal of the Geological Society, London, 136, 589-603.

Stampfli, G. 2000. Tethyan oceans. In: Bozkurt, E., Winchester, J.A. \& Piper, J.D. Tectonics and Magmatism in Turkey and the Surrounding Area. Geological Society, London, Special Publications, 173, 1-23.

Tatar, O., PiPer, J.D.A. \& Gursoy, H. 2000. Palaeomagnetic study of the Erçiyes Sector of the Eçmis Fault Zone: neotectonic deformation in the southeastern part of the Anatolian Block. In: Bozkurt, E., Winchester, J.A. \& PiPer, J.D.A. Tectonics and Magmatism in Turkey and the Surrounding Area. Geological Society, London, Special Publications, 173, 423-440.

TeKeli, O. 1981. Subduction complex of pre-Jurassic age, northern Anatolia, Turkey. Geology, 9, 68-72.

TeKIN, U.K. 1999. Biostratigraphy and Systematics of Late Middle to Late Triassic Radiolarians from the Taurus Mountains and Ankara Region, Turkey. Geologisch-Paläontologische Mitteilungen Innsbruck, Sonderband, 5, 1-296.

Ustä̈mer, T. \& Robertson, A.H.F. 1997. Tectonic-sedimentary evolution of the north Tethyan margin in the Central Pontides of Northern Turkey. In: Robinson, A.G. Regional and Petroleum Geology of the Black Sea and Surrounding Region. American Association of Petroleum Geologists, Memoir, 68, $183-226$

Yilmaz, Y., Tüysüz, O., YıĞItbaș, E., GenÇ, S.C. \& Șengör, A.M.C. 1997. Geology and tectonic evolution of the Pontides. In: Robinson, A.G. Regional and Petroleum Geology of the Black Sea and Surrounding Region. American Association of Petroleum Geologists, Memoir, 68, 183-226.

Received 19 November 2001; revised typescript accepted 15 March 2002.

Scientific editing by Alex Maltman 